\title{
A Critical Analysis of Key Financial Performance Indicators in the Banking Industry in Ghana
}

\author{
Article by Dominic Tetteh Sackitey \\ Ph.D. in Management, Texila American University \\ E-mail:neneayoo@yahoo.com
}

\begin{abstract}
The banking industry is considered to be an important source of financing for most businesses. In Ghana, the financial systems tend to evolve around the banking system. This study therefore sought to critically explore the key financial performance indicators in the banking industry. This study made use of secondary data obtained from published annual reports of Ecobank Ghana Limited from 20052015.

It was found that the Key Financial Performance Indicators for assessing the financial performance of Ecobank Ghana are:

- Profitability which is measured using the following criteria: Return on Assets (ROA), Return on Equity (ROE) and Cost to Income Ratio (CIR).

- Liquidity performance is measured using Liquid assets to deposit-borrowing ratio (LADST), Net Loans to total asset ratio (NLTA), Net loans to deposit and borrowing (NLDST).

- Asset Credit Quality (Credit Performance) is measured using Loan loss reserve to gross loans (LRGL).

- Management of the bank should ensure that Key Performance Indicators are aligned with the specific goals and objectives of the bank.

It was recommended that key performance indicators must be quantifiable. The goal must be stated in concise terms and capable of being measured. A time frame must also be established for all key performance indicators, with key checkpoints at various intervals.
\end{abstract}

Keywords: Agriculture Development Bank, Amalgamated Bank, Analysis of Variance, Accident Ratio, Automated teller machines, Business Activity Monitoring, Barclays Bank of Ghana Limited, Bank of Credit and Commerce, Bank for Housing and Construction, Cal Merchant Bank, Credit to Deposit Ratio, Credit To Deposit Ratio, Cash Flow, Cost to Income Ratio, Cash in Transit Services, Customer Loyalty, Customer Retention, Customer Satisfaction Rate, Deliver Performance to Customer Performance, Ecobank Ghana, Financial Result, Ghana Commercial Bank, Gender Ratios, Internal Efficiency, Internal Promotions, Investment Rate, Liquid Assets to Deposit-Borrowing Ratio, Loan Loss Reserve to Gross Loans, Merchants Bank of Ghana Limited, Post-Dated Cheque Collection, Performance Indicators, Point of Sale, Return On Capital Employed, Return on Equity, Return on investment.

\section{Introduction}

The banking sector is considered to be an important source of financing for most businesses. In Ghana, the financial systems tend to evolve around the banking system. As the main financial intermediary, financial institutions such as banks ensure mobilization of saving from diverse sources and allocate the savings to more productive activities, benefiting not only investors and beneficiaries of the investments but the economy at large (Gulde et al, 2006). An efficient banking system enables lower transaction cost and help bring together both the supplier and borrowers of founds to transact business at minimal or no cost.

Indeed, a banking system which efficiently channels financial resources to productive use is a powerful mechanism for economic growth (Levine, 1997). Therefore, in order to know whether there 
are continuous improvements in the efficiency performance and higher productivity of the banks and the banking sector, there is the need to measure performance. The common assumption, which underpins much of the financial performance research and discussion, is that increasing financial performance will lead to improved functions and activities of the organizations. The subject of financial performance and research into its measurement is well advanced within finance and management fields.

Studies have shown several ways of measuring the performance of organizations using key performance indicators. Key performance indicators are quantifiable measures that are used to indicate an organisations success. To do this accurately they must reflect what have been identified by an organisation as its critical success factors. Although it's possible to measure many things, an important differentiator of key performance indicators is that they are the things that are essential to the organisation if it is to achieve its identified corporate goals. It is in this light this study being conducted to critically analyze the key financial performance indicators in the banking industry.

The key performance indicators can become the sole focus of attention for an organisation, whether in the private or public sector. This may be beneficial in the short term if there is a particular issue that needs to be resolved. However, the problem is that in the long term, to concentrate solely on a single measure of success can distort the way in which an organisation performs and is perceived. This is why; it can be argued that a true measure of success can only be in a situation where a number of different measures are used. In this way a more rounded and comprehensive view of all aspects of the organisation can be obtained.

In the banking sector especially the competitive nature of the Ghanaian banking sector, choosing performance measures is a challenge. Performance measurement systems play a key role in developing strategy, evaluating the achievement of organizational objectives and compensating managers. Yet many managers feel traditional financially oriented systems no longer work adequately coupled with the problem of which financial performance indicators to use in order to have accurate picture of their performance.

\section{Objectives of study}

Generally, this study seeks to critically explore the key financial indicators in the banking industry. However, it is set to achieve the following specific objectives:

To identify the key financial indicators for assessing the financial performance of Ecobank Ghana Limited. To find out the importance of key financial indicators to banks. To assess the financial performance of Ecobank Ghana Limited for the past years. To provide financial strategies for improving bank performance. What are the key financial indicators for assessing the financial performance of Ecobank Ghana Limited? What is the importance of key financial indicators to banks? What is the financial performance of Ecobank Ghana Limited for the past ten years? What are the financial strategies for improving bank performance? The measurement of bank performance particularly commercial banks is well researched and has received increased attention over the past years (Seiford and Zhu, 1999). There have been a large number of empirical studies on commercial bank performance around the world (Yeh, 1996; Webb, 2003; Lacewell, 2003; Halkos and Salamouris, 2004; Tarawneh, 2006). However, little has been done on key financial performance indicators for measuring performance of Ghanaian banks. This study will therefore contribute to adding knowledge in this respect as far as Ghanaian context is concerned.

Furthermore, this study will provide key indicator for evaluating the performance of financial institution and this can inform bankers, government policy and regulators. On a micro-level, this study will provide data for bank performance measurement which can also help improve managerial performance by identifying best and worst practices associated with high and low measured efficiency. Bank managers can use the information in this study when looking to improve their performance and when comparing the performance of their peers and evaluate the trend of their financial performance over time. 
In order to critically explore the key financial indicators in the banking industry, the study addressed the following major topic and issues:

Profitability Performance: - The most common measure of bank performance is profitability. Profitability is measured using the following criteria:

Return on Assets (ROA) = net profit/total assets shows the ability of management to acquire deposits at a reasonable cost and invest them in profitable investments (Ahmed, 2009).

Return on Equity (ROE) = net profit/ total equity. ROE is the most important indicator of a bank's profitability and growth potential. It is the rate of return to shareholders or the percentage return on each $£$ of equity invested in the bank.

Cost to Income Ratio $(\mathbf{C} / \mathbf{I})=$ total cost /total income measures the income generated per $£$ cost. That is how expensive it is for the bank to produce a unit of output.

Liquidity performance: - Liquidity indicates the ability of the bank to meet its financial obligations in a timely and effective manner. Samad (2004:36) states that "liquidity is the life and blood of a commercial bank', The following ratios are used to measure liquidity.

Liquid assets to deposit-borrowing ratio $($ LADST) $=$ liquid asset/customer deposit and short term borrowed funds. This ratio indicates the percentage of short term obligations that could be met with the bank's liquid assets in the case of sudden withdrawals.

Net Loans to total asset ratio $($ NLTA $)=$ Net loans/total assets NLTA measures the percentage of assets that is tied up in loans. The higher the ratio, the less liquid the bank is.

Net loans to deposit and borrowing (NLDST) $=$ Net loans/total deposits and short term borrowings. This ratio indicates the percentage of the total deposits locked into non-liquid assets. A high figure denotes lower liquidity.

Asset Credit Quality (Credit Performance): - While it is expected that banks would bear some bad loans and losses in their lending activities, one of the key objectives of the bank is to minimize such losses (Casu et al, 2006). Non-performing loans is not available for all banks therefore this study will use the following ratio:

Loan loss reserve to gross loans $($ LRGL) $=$ Loan loss reserve/gross loans. This ratio indicates the proportion of the total portfolio that has been set aside but not charged off. It is a reserve for losses expressed as a percentage of total loans. This study made use of secondary data in exploring the key financial indicators in the Ghanaian banking sector. The secondary data were obtained basically from published annual reports of Ecobank Ghana Limited. The annual data for Ecobank Ghana Limited during (2005-2011) were used for calculating key financial ratios in order to assess the performance of the bank. In addition, another source of data was through reference to the library and the review of different articles, papers, and relevant previous studies. This study used a descriptive financial analysis to describe, measure, compare, and classify the financial situations of Ecobank Ghana Limited. In Ghana, the banking sector has traditionally been segmented into merchant, commercial (retail) and development banks. While merchant banks have been restricted to corporate clients, the commercial and development banks have traditionally had customers across the entire financial market segments. It is against this backdrop and the need to create a level playing field for all banks that the idea of Universal Banking (Bank of Ghana, 2004) was adopted. The aim is to allow all banks that comply with the prescribed capital requirements, the freedom to engage in permissible banking business without restrictions and thereby eliminate the compartmentalization. Hinson (2004) has noted that "before the passage of the Universal Banking Law, banking was conducted along such narrow scopes as commercial, developmental or merchant banking. With the passage of the Universal Banking Law however, all types of banking can be conducted under a single corporate banking entity and this greatly reorganizes the competitive scopes of several banking products in Ghana”. He further noted that banks in Ghana have been thrust "firmly into the competitive arena in terms of customers and products" and also that banks throughout Ghana are also "seeking unique ways of differentiating their offering". The banking system in Ghana consists of a national network of licensed and statutory financial institutions engaged in the business of banking under the banking laws of Ghana. Bank of 
Ghana is the central bank and it regulates the activities of all the banks. The banking sector over the last decade has seen appreciable growth and improvements in performance as a result of reforms instituted by governments before this period. Some of the reforms implemented include the Financial Sector Adjustment Programme (FINSAP II and I), Non-Performing Assets Recovery Trust (NPART) and the Foreign Exchange Bureau legislation. A new Banking Law was also promulgated.

The Bank of Ghana was strengthened to enhance its capacity to play its regulatory role.

These reforms have; strengthened the banks in terms of their capital base and managerial competence; enhanced supervisory capabilities of Bank of Ghana; improved the quality of assets being held by banks; increased profitability of the banks.

From independence to 1983, there were twelve (12) banks. These banks were Standard Chartered Bank (SCB), Barclays Bank of Ghana Limited (BBG), Ghana Commercial Bank (GCB), Bank for Housing and Construction (BHC), Agriculture Development Bank (ADB), Bank of Credit and Commerce (BCC), Merchants Bank of Ghana Limited (MBG), Social Security Bank (SSB), National Investment Bank, Ghana Corporative Bank (Co-op), Cal Merchant Bank (CAL) and Ecobank (ECO). Over the last decade (1993-2003) and beyond eleven (11) new banks have been incorporated namely: Prudential Bank Ltd (PBL), Metropolitan Allied Bank (METRO), First Atlantic Merchant Bank (FAMB), The Trust Bank (TTB), International Commercial Bank (ICB), Stanbic Bank, Amalgamated Bank (AMALBANK), HFC Bank, Unibank, Prestige Bank and Standard Trust Bank. Some significant events have occurred during this period such as mergers (SG-SSB, and National Savings and Credit Bank), liquidation (BHC, Co-op), privatization of state owned banks and change of ownership (GCB, SSB, NIB). Competition in the banking sector has escalated over the period. Commercial and development banks have gone beyond their limit and have ventured into international trade financing, commerce and corporate lending, treasury services payment financing, syndication, etc., which used to be the preserve of merchant banks. One area that has seen fierce competition in the banking industry is the area of product development. New products such as international funds transfer, school fees loan, negotiable certificate of deposit, car loans, consumer/hire purchase loan, travelers' cheque, etc. have been developed. Another development that has occurred over the last decade is computerization and networking of branches. Some of the banks have a nationwide network whilst others have reached an advanced stage of networking all their branches. Banks operations and information processing have vastly increased. Automated teller machines (ATMs) have become common, giving clients the freedom to transact business at their own convenience. Also home banking, for example telephone banking, SMS banking, etc. have been introduced. The banks have pursued consistent programmes of sponsor Banks ship, promotion, advertisement of services and products in the print and electronic media, etc. The banking sector landscape can be said to be evolving, competitive and promising in terms of savings mobilization, development financing and service delivery.

\section{The universal banking law and its ramifications}

Universal Banking (UB) has been in existence for a very long time in several countries. Countries such as France, Germany were the pioneers of what has become known as Universal Banking (Gockel, 2003)

Some of the definitions of universal banking are as follows:

Banking that includes investment services in addition to services related to savings and loans (investopedia.com)

Banks offering entire arrays of banking services (Rich and Walter, 1993)

A one-stop supplier of all financial products and activities like deposits, short term and long term loans, insurance and investment banking, etc.

A corporate structure where large banks operate extensive network of branches, providing many different services, hold several claims on firms (including equity and debt), and participate directly in 
the corporate governance of firms that rely on banks for funding or as insurance underwriters (Addison, 2003).

Although universal banking is practiced in several countries, there are basically three forms: inhouse, separate subsidiaries or holding company. In Germany, investment and commercial banking are allowed in-house but separate subsidiaries are required for certain other activities. In the UK, the banks are allowed to conduct a wide range of financial activities through separate subsidiaries. The United States has adopted the holding company model and it requires separate capitalized subsidiaries (Bokhari, 2004). From the fore-gone exposition, the concept of universal banking is clear. However, the scope and implementation are different from one country to another. By taking cognizance of the laws and regulations governing banking, the Ghanaian model of universal banking focuses on money markets activities. Therefore capital market activity and insurance business are excluded from universal banking in the country. The definition of universal banking in the Ghanaian context is: The businesses of accepting deposits and other repayable funds from the public, lending, investments in financial securities and money transmission services, the issuance and administration of means of payment, including credit cards, travellers' cheques and bank drafts; the issuance of guarantees and commitments trading for own account or for account of customers in money market instruments, foreign exchange or transferable securities, provision of advice on capital structure, acquisitions and mergers; portfolio management and advice; safe custody of valuables; electronic banking and any other services that the Bank of Ghana may determine.

A legal requirement for a bank to be issued with a universal banking license is a minimum paid up capital of three hundred thousand billion cedis. Existing banks can satisfy this requirement through paid up capital, reserves and retained earnings. Therefore, banks with net worth of or in excess of three hundred billion cedis are eligible to apply for a universal banking license. Merchant banks namely Ecobank, Merchant Bank Ghana Ltd and CAL Bank have fulfilled the Bank of Ghana requirement and have been issued with a UB license. Also, two development banks namely ADB and NIB have satisfied the requirement. Although commercial banks have been practicing universal banking, legally only GCB, BBG, SCB, and SG-SSB are qualified. Accordingly, universal banking has relaxed restrictions and provided equal market opportunities for banks and maintained fair competition. As a result, all banks can operate merchant, retail and development banking. The benefit of this policy (law) is that a bank will determine the area it wants to focus on based on its competence and competitive advantage. With the passage of the Universal Banking Law however, all types of banking can be conducted under a single corporate banking entity and this greatly reorganizes the competitive scopes of several banking products in Ghana. The years of reform and deregulation have brought the banking sector firmly into the competitive arena in terms of customers and products. Banks have seen unprecedented upheaval. A mutual fund product from a Non-Bank Financial Institution for example would compete with a mutual fund product from a traditional bank. A traditional brokerage firm would have to compete for Initial Public Offering (IPO) business with the several subsidiaries that exist under traditional banking umbrella brands. In the light of all these interesting developments in Ghana's banking industry therefore, it becomes necessary to ask what role quality service plays in this new banking paradigm. Banks throughout the country are constantly seeking unique ways of differentiating their offering. The willingness and ability of managers in Banks to respond to changes in the service economy will determine whether their own organizations survive and prosper. With so many changes occurring in the Ghanaian banking sector, including an expansion and intensification of competition and increasing customer sensitivity, the issue of service quality has gained considerable currency.

\section{Performance evaluation of commercial banks}

The measurement of bank performance particularly commercial banks is well researched and has received increased attention over the past years (Seiford and Zhu, 1999). There have been a large number of empirical studies on commercial bank performance around the world (see Yeh, 1996; 
Webb, 2003; Lacewell, 2003; Halkos and Salamouris, 2004; Tarawneh, 2006). However, little has been done on bank performance in South Africa. However, with the deteriorating health of the banking institutions and the recent surge of bank failures as a result of the current global financial crisis, it is justified that bank performance receives increased investigation from both scholars and industry specialists. There are two broad approaches used to measure bank performance, the accounting approach, which makes use of financial ratios and econometric techniques. Traditionally accounting methods primarily based on the use of financial ratios have been employed for assessing bank performance (Ncube, 2009). However, the limitations of this method coupled with advances in management sciences have led to the development of alternate methods such as non-parametric DEA and parametric Stochastic Frontier Approach (hereafter, SFA) (Berger and Humphrey, 1997).

Berger \& Humphrey (1997) assert that the whole idea of measuring bank performance is to separate banks that are performing well from those which are doing poorly. They further indicated that, "evaluating the performance of financial institution can inform government policy by assessing the effects of deregulation, mergers and market structure on efficiency" (p175). Bank regulators screen banks by evaluating banks' liquidity, solvency and overall performance to enable them to intervene when there is need and to gauge the potential for problems (Casu et al, 2006). On a micro-level, bank performance measurement can also help improve managerial performance by identifying best and worst practices associated with high and low measured efficiency. When looking to improve their performance, banks compare the performance of their peers and evaluate the trend of their financial performance over time. Tarawneh (2006) in his study measured the performance of Oman commercial banks using financial ratios and ranked the banks based on their performance. The study utilised FRA to investigate the impact of asset management, operational efficiency and bank size on the performance of Oman commercial banks. The findings indicated that bank performance was strongly and positively influenced by operational efficiency, asset management and bank size. In the Gulf, Samad (2004) investigated the performance of seven locally incorporated commercial banks during the period 1994-2001. Financial ratios were used to evaluate the credit quality, profitability, and liquidity performances. The performance of the seven commercial banks was compared with the banking industry in Bahrain which was considered a benchmark. The article applied a Student's $t$-test to measure the statistical significance for the measures of performance. The results revealed that commercial banks in Bahrain were relatively less profitable, less liquid and were exposed to higher credit risk than the banking industry, in which wholesale banks are the main component. Kiyota (2009) in a two- stage procedure investigated the profit efficiency and cost efficiency of commercial banks operating in 29 Sub-Saharan African countries during 2000-2007. The article employs the SFA for the estimation of profit and cost efficiency, financial ratios and the Tobit regression to provide cross-country evidence on the performance and efficiency of African commercial banks. The findings based on a range of performance ratios as well as stochastic cost and profit frontier estimation, suggest that foreign banks tend to outperform domestic banks in terms of profit efficiency as well as cost efficiency. The results are also in line with the research by Kirkpatrick et al (2007) who used a sample of 89 banks from Sub-Sahara African countries for the period 1992-1999 and found that banks are on average $67 \%$ profit efficient and $80 \%$ cost efficient, as indicated by the results from both the distribution free approach and SFA methods. O’Donnell and Van der Westhuizen (2002) measured the efficiency of a South African bank at branch level. Their main focus was investigating branches which were performing well and those that were doing badly, where efficiency could be improved. They found that many branches were operating on a scale that is too small and could increase their operational scales thereby improving the overall efficiency of the bank. In a similar approach, Okeahalam (2006) used the Bayesian SFA to assess the production efficiency of 61 bank branches in nine provinces of South Africa. The findings of the study points to the fact that although every branch is operating at increasing returns to scale, the bank branches can reduce their cost by $17 \%$ if they improve the level of efficiency. Overall the article concludes that the bank branches are less efficient than they should be and could obtain cost reductions by increasing output. Further, Oberholzer and 
Van der Westhuizen (2004) investigated the efficiency and profitability of ten banking regional offices of one of South Africa's larger banks. The study demonstrates how conventional profitability and efficiency analyses can be used in conjunction with DEA. Although their study concentrated on banking regions, their findings confirm those of Yeh (1996) that DEA results as an efficiency measure have a relationship with both profitability and efficiency ratios. The conclusions were that there are significant relationships between conventional profitability and efficiency measures and allocative, cost and scale efficiency and no significant relationship with technical efficiency. Most of the above mentioned studies concentrated on branches of a single bank, one of the studies that investigated the entire South African banking sector is Cronje (2007) who employed the DEA method and a sample of 13 South African banks to provide a measure of the efficiency of the South African banks. His findings show that out of the 13 banks, the three largest banks are efficient and serve as a standard for the banks classified as inefficient. The fourth largest bank showed a slight inefficiency. Overall, seven banks were classified as inefficient and the article recommends target areas for the banks to improve their efficiencies with guidelines that bankers in inefficient banks could use to increase their sustainable profitability. The results of this study are in sharp contrast to studies in the UK where Drake (2001) and Webb (2003) found the larger banks less efficient. This difference could be attributed to the differences in operating environment as South Africa is an emerging economy with a different political and economic history where as UK is a developed country. Another study that provides a brief but interesting account of bank performance was conducted by Ncube (2009) who uses the stochastic frontier model to analyse the cost and profit efficiency of four large and four small South African banks. The results of the study show that South African banks have significantly improved their cost efficiencies between 2000 and 2005 with the most cost efficient banks also being most profit efficient. However, efficiency gains on profitability over the same time period were found not to be significant. The trend of commercial banking is changing rapidly. Competition is getting stiffer and, therefore, banks need to enhance their competitiveness and efficiency by improving performance. Normally, the financial performance of commercial banks and other financial institutions has been measured using a combination of financial ratios analysis, benchmarking, measuring performance against budget or a mix of these methodologies (Avkiran, 1995). Gopinathan (2009) has presented that the financial ratios analysis can spot better investment options for investors as the ratio analysis measures various aspects of the performance and analyzes fundamentals of a company or an institution. Furthermore, Ho and Zhu (2004) have reported that the evaluation of a company's performance has been focusing the operational effectiveness and efficiency, which might influence the company's survival directly. The empirical results of the researches (Raza et al., 2011; Tarawneh, 2006) explained that a company, which has better efficiency, it does not mean that always it will show the better effectiveness. Alam et al. (2011) study concludes that ranking of banks differ as the financial ratio changes. Bakar and Tahir (2009) in their paper used multiple linear regression technique and simulated neural network techniques for predicting bank performance. ROA was used as dependent variable of bank performance and seven variables including liquidity, credit risk, cost to income ratio, size and concentration ratio, were used as independent variables. They concluded that neural network method outperforms the multiple linear regression method however it need clarification on the factor used and they noted that multiple linear regressions, not withstanding its limitations, can be used as a simple tool to study the linear relationship between the dependent variable and independent variables.

Neceur (2003) using a sample of ten Tunisian banks from 1980 to 2000 and a panel linear regression model, reported a strong positive impact of capitalization to ROA.

There are number of studies, which examine the bank performance using CAMEL framework, which is the latest model of financial analysis. Elyor (2009) and Uzhegova (2010) have used CAMEL model to examine factors affecting bank profitability with success. The CAMEL Framework is the most widely used model (Baral, 2005). The Central bank of Nepal (NRB) has also implemented CAMEL Framework for performance evaluation of the banks and other financial institutions. 
CAMEL stands for capital adequacy, asset quality, management efficiency, earnings performance and liquidity. The capital adequacy ratio is a key measure to determine the health of banks and financial institutions. Capital adequacy refers to the sufficiency of the amount of equity to absorb any shocks that the bank may experience (Kosmidou, 2008). Nepalese commercial banks need to maintain at least 6\% Tier-1 capital and 10\% total capital (Tier 1 and Tier 2), that is, core capital and supplementary capital respectively. Tier 1 capital consists of paid-up capital, share premium, non-redeemable preference share, general reserve fund, accumulated profit, capital redemption reserve, capital adjustment fund, and other free reserves. The Tier 2 capital comprises of capital comprises of general loan loss provision, assets revaluation reserve, hybrid capital instruments, subordinated term loan, exchange equalization reserve, excess loan loss provision, and investment adjustment reserve. These minimum capital adequacy requirements are based on the risk-weighted exposures of the banks (NRB, 2010). Credit risk is one of the factors that affect the health of an individual bank while asset quality analysis involves taking account of the likelihood of borrowers paying back loans. The extent of the credit risk depends on the quality of assets held by an individual bank. The quality of assets held by a bank depends on exposure to specific risks, trends in non-performing loans, and the health and profitability of bank borrowers (Baral, 2005). Poor asset quality and low levels of liquidity are the two major causes of bank failures. Poor asset quality led to many bank failures in Kenya in the early 1980s (Olweny and Shipo, 2011). NRB uses composition of assets, nonperforming loan to total loan ratio, net nonperforming loan to total loan ratio as the indicators of the quality of assets of the commercial banks (NRB, 2010). The maximum NPL allows for a healthy bank is $5 \%$. Management quality plays a big role in determining the future of the bank. The management has an overview of a bank's operations, manages the quality of loans and has to ensure that the bank is profitable. Rahman et al. (2004) and Elyor (2009) noted that interest expenses divided to total loans can be measured as the bank management quality. Ability to support the present and future operations of a bank depends on the quality of its earnings and profitability profile (Share et al., 2011). NRB uses return on total assets as an indicator of profitability of a commercial bank. In addition, it uses the absolute measures such as interest income, net interest income, non-interest income, net non-interest income, nonoperating income, net no operating income and net profit, to evaluate the profitability of a commercial bank (NRB, 2010). Liquidity management is one of the most important functions of a bank. If funds tapped are not properly utilized, the Jha and Hui 7603 institution will suffer loss (Sangmi and Nazir, 2010).

\section{Factors influencing profitability of commercial banks}

Sampath (1990) examined the factors influencing profitability of commercial banks. According to him, profit means the excess of total revenue over total expenses, where of profitability means the rate of return on working funds. Further he emphasized that profitability depends on certain factors like interest income, interest expenses and manpower expenses, other expenses and non-interest income. Padna and Lall (1991) in their research work papers were presented of their views that improvement in profitability through the development of certain internal management techniques. They concluded that productivity deployment of funds, quality of advances, information system and organization setup and branch expansion are the factors which influence the profitability of banks to the great extent. Amandeep (1993) examined the trends in profits and profitability of 20 nationalized banks, by using the analytical tools, i.e. trend analysis, ratio analysis and concentration indices of the selected parameters. The study concluded that the efficient management of burden plays a significant role in the determination of profitability of banks. Satyamurthy (1994) in his study clarified the concepts of profits, profitability and productivity applicable to the banking industry. It was organized by the bank managements that the pressure on the profitability was more due to the factors beyond their control. He suggested the technique of ratio analysis to evaluate the profit and profitability performance of banks. Sarker and Das (1997) in their study compared the performance of public, private and foreign banks for 1994-95 by using measures of profitability, productivity and financial management. They 
fought that public sector banks comparing poorly with the other two categories. However they caution that no firm inference can be derived from a comparison done for a single year. Sarkar (1999) examined the Ownership Impact of Banks Profitability. The study concluded that the foreign banks were profitable and efficient than Indian banks and amongst the Indian private banks were superior to the public sector banks. John Goddard et al., (2004) in their study examined models for the determinants of profitability. Despite intensifying competition there is significant persistence of abnormal profit from year to year. The evidence for any consistent or systematic size-profitability relationship was relatively weak. The relationship between the importance of off-balance-sheet business in a bank "s portfolio and profitability was positive for the UK, but either neutral or negative elsewhere. The relationship between the capital-assets ratio and profitability was positive. Toni Uhomoibhi Aburime (2008) in his study made an attempt to study the impact of ownership structure on bank profitability in Nigeria. The study examines whether the composition and spread of bank ownership significantly impinges on bank returns. Using 98 commercial and merchant banks in 478 observations over the 1989-2004 periods, regression and t-test results suggest that the composition and spread of ownership has had no significant effect on bank profitability in Nigeria. Uppal (2009) examined the profitability which is an important criterion to evaluate the overall efficiency of a bank group. The paper examines the comparative trends in profitability behaviors of five major bank groups in the post liberalization and globalization era. The paper offers suggestions on the basis of empirical results to increase the profitability and measures should be taken to increase the level spread and curtail the burden.

\section{Tools for the financial statement analysis}

The tools for the financial statement analysis are the financial ratios which can be used to answer some important questions regarding a company's/ customer's well-being.

Such very important questions regarding are:

(a) How liquid is the company?

(b) Is management generating sufficient profits from the company's assets?

(c) How does the company's management finance its investments?

The answer to these questions is Ratio Analysis. According to UBAKA (1996), ratio is defined as a useful tool with which to analyse a set of financial statements. It is the only such tool available to accountants to analyse a set of financial statements. Ratio is the arithmetic relationship between two figures in a set of financial statement. It can be presented in a number of forms. The particular form of presentation chosen for any relationship examined is the one which the analyst can best interpret, for instance, some people prefer to look at the periods, while others prefer percentage presentation.

The three basic financial statements which form the bedrock from which the financial ratios are usually computed for analysis are:

(a) Balance sheet which represents a statement of financial position of a firm at a given period of time, including asset-holding, liabilities and owner's equity.

(b) Profit and loss statement (which is sometimes referred to as income statement) presents a measure of the net profit results of the firm's operations over a specified interval. It is computed on an accrual rather than on a cash basis.

(c) Statement of charges in financial position (which is also known as sources and use of adds statement provides an accounting for the sources provided during a specified period and the uses which they are put).Analysis of the above financial statements employing financial ratios requires low arithmetical skill. Ratios are of use principally to the higher levels of management, who are responsible for maximizing profits and planning for the future. One must understand the inner workings of the financial ratios and the significance of various financial relationship to interpret he data bearing in financial analysis as to provide information about an establishment and such information do not be limited to accounting data. Ratios based on past performance may be helpful in predicting future earnings capacity 
and financial projections of an establishment. Financial statement is merely a summary records of the past and we have go beyond the financial statement and look into the nature of the organization, its position within economy, its activities, its research expenditures and above all, the quality of its engagement before granting loan (MATHER 1979). Financial ratios are of four types and are used to analyse the financial position of a firm.

Liquidity ratios: These ratios indicate the firm's capacity to meet short-run obligations. Liquidity ratios measure the firm's ability to fulfill short-term commitments out of its liquid assets. These ratios particularly interest the firm's short-term creditors liquid assets include accounts receivable and other debts owed to the firm which will generate cash when those debts are paid in the near future. Also included are cash and other assets as marketable securities and inventories either of which can be sold to generate funds for meeting maturing short-run obligations. Two types of liquidity ratios are the current and quick ratio.

Current ratio: The simplest measure of the firm's ability to raise funds to meet short-run obligations is the current ratio. It is the ratio of Current Assets to current liabilities. Current assets are viewed as relatively liquid which means they can generate cash in a relatively short time period. If current ratio is too low, the firm may have difficulty in meeting short-run commitments as they mature. If it is too high, the firm may have an excessive investment in current asset. To reduce a high current ratio, the component(s) of current asset that is too large should be reduced and the funds invested in more productive long-term assets used to reduce debt or paid out as dividends to the owners of the firm.

\section{Current Ratio $=\quad$ Current Asset \\ Current Liability}

Quick or acid test ratio: Measures the firm's ability to meet short-term obligations from its most liquidity assets. In this case, inventory is not included with other current assets because it is generally far less liquid than the other current assets excluding inventory dividend by current liabilities. Thus:

Quick Ratio $=$ Current Assets Less Inventory or Stock .

\section{Current Liability}

Leverage Ratios: Measure the extent of the firm's total debt burden. They reflect the firm's ability to meet its short and long term debt obligations. These ratios are computed either by comparing fixed charges and earning from the income statement or by relating the debt and equity items from the balance sheet. These leverage ratios are important to creditors since they reflect the capacity of the firm's revenue to support interest and other fixed charges and whether there are sufficient assets to pay off debt in the event of liquidation. Shareholders too, are concerned with these ratios, since interest payments are an expense to the firm that increases with greater debt. If borrowing and interest are excessive, the firm can even experience bankruptcy. Leverage ratio is of three types which include:

Debt-to-total assets ratio: This ratio equals total debt divided by total assets. Thus: Debt to total asset ratio $=$ Total debt (liabilities)

\section{Total Assets}

Thus ratio is also referred simply as a debt ratio generally, creditors prefer a low debt ratio since it implies a greater protection of their position. A higher debt ratio generally means that the firm must yield a higher interest rate on its borrowing, beyond some point the firm will not be able to borrow at all. Times Interest Earned Ratio divided by interest

Thus, equals Earnings before Interest and Taxes.

(EBIT) Thus EBIT Interest charges

This ratio reflects the firm's ability to pay annual interest on its debt out of its earnings. Here creditors feel highly confident that the debt interest will be paid since interest is amply covered by Earnings before Interest and Taxes (EBIT). 
Fixed charges coverage Ratio: This equals income available to meet fixed charges divided by fixed charges. Fixed charges include all fixed naira outlays, including debt interest, sinking fund contribution and lease payments. A fixed charge is a cash outflow that the firm cannot avoid without violating its contractual agreements. The firm periodically deposits money in a sinking fund which is eventually used to pay off the principal of the long term debt for which the fund was set up fixed charges coverage

$=\quad$ Income available for meeting fixed charges

Fixed charges

That is,

Operating income + lease payment + other incomes

Interest + lease payment + before tax as sinking fund contribution

Fixed charges coverage ratio indicates how much income there is to pay for all fixed charges.

Activity Ratios: Indicate how effectively the firm uses its total assets in generating sales. These ratios indicate whether the firm's investments in current and long term assets are too small or too large. If the investment in assets is too large, it could be that the funds tied up in that asset should be used for more immediate productive purposes. And if the investment is too small, the firm may be providing poor service to customers or inefficiently producing its product. Under the umbrella of activity ratio:

Inventory Turnover which equals cost of goods sold divided by average inventory turnover implies a large stock outs. A low inventory turnover implies a large investment in inventories relative to the amount needed to service sales. Excess inventory ties up resources unproductively. On the other hand, if the inventory turnover is too high, inventories are too small and it may be that the firm is constantly running short of inventory (out of stock) thereby losing customers. The objective of this ratio is to maintain a level of inventory relative to sales that is not excessive but at the same thing or time, is sufficient to meet customer needs.

Average collection period: This is a measure of how long it takes from the time the sale is made to the time the cash is collected from the customer. This ratio indicates the firm's efficiency in collecting in its sales. It may also reflect the firm's credit policy. The sooner the firm receives the cash due to sales, the sooner it can put that money to work earning interest.

Fixed Assets Turnover: This reflects how well the firm's assets are being used to generate sales. This indicates how intensively the fixed assets of the firm are being used in adequately low ratio implies excessive investment in plan and equipment relative to the value of output being produced.

Total Assets Turnover: This reflects how well the firm's assets are being used to generate sales. If it low, it indicates the excessive investment in fixed assets (James and Horne 1989).

Profitability Ratios: These ratios measure the success of the firm in ensuring a net return on sales or investment. Since profit is the ultimate objective of a firm, poor performance indicates a basic failure which if not corrected over too long a time would probably result in the firm's going out of business under the umbrella of profitability ratios we have:

Return on Equity (ROE): This is the best single measure of the measure of the firm's success in fulfilling its goal. Management objective is to generate the maximum return on shareholders investment in the firm. At the end of this work, the problems of bank lending would have been revealed and a way of achieving effective and efficient bank lending through careful analysis and use of financial statements in appraisal if borrower's loan application before lending.

\section{Advantages and uses of ratio analysis}

There are various groups of people who are interested in analysis of financial position of a company. They use the ratio analysis to work out a particular financial characteristic of the company in which they are interested. Ratio analysis helps the various groups in the following manner: -

To workout the profitability: Accounting ratio help to measure the profitability of the business by calculating the various profitability ratios. It helps the management to know about the earning 
capacity of the business concern. In this way profitability ratios show the actual performance of the business.

To workout the solvency: With the help of solvency ratios, solvency of the company can be measured. These ratios show the relationship between the liabilities and assets. In case external liabilities are more than that of the assets of the company, it shows the unsound position of the business. In this case the business has to make it possible to repay its loans.

Helpful in analysis of financial statement: Ratio analysis help the outsiders just like creditors, shareholders, debenture-holders, bankers to know about the profitability and ability of the company to pay them interest and dividend etc.

Helpful in comparative analysis of the performance: With the help of ratio analysis a company may have comparative study of its performance to the previous years. In this way company comes to know about its weak point and be able to improve them.

To simplify the accounting information: Accounting ratios are very useful as they briefly summarise the result of detailed and complicated computations.

To workout the operating efficiency: Ratio analysis helps to workout the operating efficiency of the company with the help of various turnover ratios. All turnover ratios are worked out to evaluate the performance of the business in utilising the resources.

To workout short-term financial position: Ratio analysis helps to workout the short-term financial position of the company with the help of liquidity ratios. In case short-term financial position is not healthy efforts are made to improve it.

Helpful for forecasting purposes: Accounting ratios indicate the trend of the business.

Determinants of Key Performance Indicators (KPIS) Of Private Sector Banks In Srilanka: An Application Of Exploratory Factor Analysis (By Balasundaram Nimalathasan (2009) Department of Commerce, University of Jaffna, Jaffna, SriLanka Fascicle of the Faculty of Economics and Public Administration Vol. 9, No. 2(10), 2009)

In an attempt to fill the gap, the main objective of the article was to determine the key performance indicators (KPIs) of private sector banks in SriLanka with samples of hundred respondents in twelve branches in North and Eastern Provinces. Data were collected through a five points Likert type summated rating scales of questionnaire from strongly disagree (1) to strongly agree (5) were adopted to identify indicators. Sophisticated statistical model as "Exploratory Factor Analysis" (EFA) has been used.

The results of the findings show that eight factors extracted from the analysis that together accounted $73.781 \%$ of the total variance. According to the article, while there is certainly value in historical analysis, it is a fundamental principle of Key Performance Indicators (KPIs) to be current or forward -looking metrics. The article stated that it is also critical that KPIs be closely aligned to strategic company goals and implemented in such a way as to support positive change. KPIs are financial and non-financial metrics used to help an organization define and measure progress toward organizational goal s. the article argued that KPIs can be delivered through business intelligence techniques to assess the present state of the business and to assist in prescribing a course of action. The article posited that KPIs are quantifiable measurements, agreed to beforehand, that reflect the critical success factors of an organization. According to the article, whatever KPIs indicators are selected, they must reflect the organization's goals, they must be key to its success, and they must be quantifiable (measurable). KPIs usually are long-term considerations. The definition of what they are and how they are measured do not change often. The article stated that the goals for particular KPIs may change as the organization's goals change, or as it gets closer to achieving a goal. The act of monitoring KPIs in real -time is known as Business Activity Monitoring (BAM). KPIs are frequently used to "value" difficult to measure activities such as the benefits of leadership development, engagement, service, and satisfaction. The article explained further that KPIs are typically tied to an organization's strategy (as exemplified through techniques such as the Balanced Score Card). To identify potential underlying dimensions of the KPIs of private sector banks development used in the 
current study, responses of the participants were subjected to factor analysis method. Before applying factor analysis, testing of the reliability of the scale is very much important as its shows the extent to which a scale produces consistent result if measurements are made repeatedly. This is done by determining the association in between scores obtained from different administrations of the scale. If the association is high, the scale yields consistent result, thus is reliable. According to the article Cronbach's alpha is most widely used method. It may be mentioned that its value varies from 0 to 1 but, satisfactory value is required to be more than 0.6 for the scale to be reliable. Its value is estimated to be 0.653 . If compare reliability value with the standard value alpha of 0.6 advocated by Cronbach (1951), a more accurate recommendation or with the standard value of 0.6 as recommended, the article found that the scales used by us are highly reliable for data analysis. The article stated that Performance Indicators (PIs) have been implemented in many countries, from the United Kingdom (UK) to Australia labelled as essential management information and a management tool, as well as claimed to bring about numerous benefits (e.g., improved accountability and planning), PIs are expected to be increasingly used however, the literature on performance indicators suggests that their application may bring about dysfunctional effects. In particular, authors from countries such as the UK, United State of America (USA) and the Netherlands had voiced their concerns that performance indicators could set the criteria for performance. Performance measurement and reporting is now widespread across the private sector as well as public sector of many industrialized and industrializing countries. According to the article the common tool that is used for this process, key performance indicators (KPIs), have been argued to provide 'intelligence' in the form of useful information about a public and private agency's performance. The article argued that great is this faith in KPIs that many public and private agencies are now mandated by law or executive order to use them as one of the primary tools to account for their performance to main public accountability or reporting authorities, such as the Parliament and the Government auditor. It is apparent that, the way in which KPIs work to improve accountability is through the information they provide to the principal. Performance measurement systems assume that humans can use the information to make better decision. This assumption is consistent with the rational -comprehensive and bounded rationality perspectives on decision - making. The former perspective describes information as directly related to organisational goals and the organisational methods by which to achieve these goals. It also views information as available, unambiguous and directly influential on decisions. Many scholars have maintained that the implementation of performance measurement systems possesses important symbolic value. According to the article KPIs are viewed as a 'good' management device and a socially constructed tool that makes sense. The article found that the fact that KPIs tend to be quantitative has helped to promote their image of objectiveness and rationality. It stated that the image of KPIs is further enhanced by their widespread application across the public sector of many industrialised countries. The article argued that the importance of performance measurement and that it is important to expect that citizens see and understand the results of government programs. It is necessary that public employees and their leaders not play their thumbs when public dollars are wasted on poorly planned or unrealistic public programs. Based on this analysis, the article posited that there are no comprehensive and empirical researches in that field especially in private sector banks viz., EFA. In an attempt to fill in this gap, the article conducted the determinants of key performance indicators (KPIs) of private sector banks in SriLanka with samples of hundred respondents in twelve branches in North and Eastern Provinces. Through an empirical investigation, the article has identified eight indicators that are major contributors to the performance of the private sector banks in North and Eastern provinces of SriLanka. These factors in order of importance are (1) AR; (2) OSR; (3) CF; (4) ROCE; (5) CSR; (6) OEE; (7) ROI and (8) IP.

The above article identified eight indicators that are major contributors to the performance of the private sector banks in North and Eastern provinces of SriLanka. It is important to note that an efficient banking system facilitates linkage between mobilization and use of resources, which accelerates the process of economic growth. It is a widely accepted belief that a banking system which 
relies on a wide array of banking products, is able to carry out this function because it increases the efficiency of a banking systems to a large extent by offering a broader and flexible arrange of services to the benefits of both borrowers and investors. Meanwhile, there are no comprehensive and empirical researches in that field especially in banking sector. These factors were categorized as 1) Accident Ratio (AR); (2) Opportunity Succession Rate (OSR); (3) Cash Flow (CF); (4) Return on Capital Employed (ROCE); (5) Customer Satisfaction Rate (CSR); (6) Overall Equipment Effectiveness (OEE); (7) Return on Investment (ROI); (8) Internal Promotion (IP).

The Use of Key Performance Indicators for a comparison of financial performance of commercial banks: A case study of Nepal. African Journal of Business Management Vol. 6(25), pp. 7601-7611, 27 June, 2012 (by Suvita Jha and Xiaofeng Hui) Available online at http://www.academicjournals.org/AJBM DOI: 10.5897/AJBM11.3073 ISSN 1993-8233 @2012 Academic Journals

The specific and general objective of the article was evaluate the financial performance of commercial banks in Nepal using Key Performance Indicators (KPIs) and find out which KPIs are relevant to assessing the performance of the commercial banks. The employed the use of a descriptive financial ratio analysis to measure, describe and analyse the performance of commercial banks in South Africa during the period 2005-2016. Additionally, to examine whether the difference in performance of the banks in 2005-2016 is statistically different from that of 2008-2009 a student's $t$ test is employed to test the hypothesis that the means of the two periods are the same on the seven variables.

The findings according to the article on the position of profitability commercial banks in Nepal was that the performance was measured with the return on assets and return on equity. The article stated that Return on assets (ROA) is a comprehensive measure of overall bank performance from an accounting perspective. The article argued that the average ROAs of all the premeditated banks have been estimated positive demonstrates that in the recent years, the performance of the banking system in Nepal is reasonable in terms of net profit. It stated that the average ROA of PSB (2.37\%) was found higher than that of JVB (1.77\%) and DPB (1.33\%) due to having utmost total assets. The earning performance of PSB was satisfactory and no public banks were suffered from net operating loss. Among the public sector banks, the average ROA of RBBL bank was determined 3.34\% with positive trend during the study period. The net profit to total assets ratio of RBBL bank to gain profit seemed most attractive due to proper mobilization of available resources than other public banks has appeared better position. The second position was for ADBL bank with average ROA equaled to $1.94 \%$. Over the study period, there was a positive trend in ROA. The last position was belonged to NBL bank with average ROA equaled to $1.84 \%$ but ROA values computed during the study period were found positive. SCBL was maintained first place with ROA equaled to $2.51 \%$ among joint venture banks, while the second position was for NABIL bank (2.48\%) and the last position was belonged to NSBI (1.13\%). The average ROA of BOK was noted $1.89 \%$ and this bank was ranked first position among the domestic private banks. The second position was for LBL bank with ROA equaled to $1.82 \%$ and the last position was belonged to NCCBL with ROA equaled to $0.43 \%$. The Jha and Hui 7605 average ROAs of NCCBL (JVB), MPBL (DPB) and LXBL (DPB) were estimated less than 1 fall in the marginal earning performance (Baral, 2005). As ROAs of the most of the larger banks were estimated greater than those of the smaller banks, it can be concluded that the larger banks were successful in mobilizing their available resources more effectively. Furthermore, availability of limited number of assets restricts the proper utilization of resources and ultimately the earning profit. According to the article the ROE of the major commercial banks in Nepal are presented for the average of the six years. The situation of PSB was most awful with fluctuating and negative ROE trends. The average ROE ratio was $-12.89 \%$ for NBL, $-12.42 \%$ for $\mathrm{RBBL}$ and $6.44 \%$ for ADBL. This implies that the shareholders receive very low returns in terms of dividend. The ROE of ADBL was only estimated in positive among the three public banks. It seems ADBL was efficiently utilizing its shareholders' funds. The average ROEs for the JVB were noted better than PSB and stood positive over the period 
2005 to 2010. In order to rank the JVBs based on this ratio, SCBL was the first one; it has an average ROE of 33.83\%. The second position was for NABIL with ROE equaled to 31.87\%, and the last position was belonged to NBBL with ROE equaled to $8.44 \%$. It shows that JVB had satisfactory earning profit and the shareholders earn better return on their investment. The average ROEs of all DPB were going positive except that of LBL. In order to rank the banks based on this ratio, NCCBL was the first one. It had an average ROE of 57.25\%. The second position was for BOK with ROE equaled to $24.65 \%$, and the last position was belonging with LBL with ROE equaled to $-3.31 \%$. It shows DPBs were efficiently use their shareholders' funds and earning net profit in satisfactory level.

Capital adequacy:- As stated in the foregoing analysis, the article stated that banks under in Nepal are well capitalized and they are complying with the directive of NRB on capital adequacy ratio. However, their capital base relative to the risk-weighted assets is not so strong. According to the international rating convention, total capital should be greater than $19.5 \%$ of the total risk weighted assets of commercial banks in order to be a strong capital base. However, none of the banks under study had the capital fund greater than $19.5 \%$ of the total risk weighted capital. As indicated by CAR, on the average, capital adequacy of joint venture banks was fair during the study period. Total capital adequacy ratio less than 15 and equal to 12 indicates that capital adequacy is fair and on the average, this ratio falls within this range.

The article stated that it is clear from that the average capital adequacy ratio of two public banks NBL and RBBL were negative due to the heavy accumulated losses. Due to the inherent problems and big chunk of NPA, the public sector banks suffered from massive losses in the past, which had heavy impact on their capital adequacy. Although, the public banks had started to improve their financial condition, it is very different from an acceptable standard. However, ADBL capital adequacy ratio was seemed to be positive but ADBL was also not achieved the NRB requirement. Most of the joint venture banks have accomplished the capital adequacy ratio as directed by NRB. The banks with noncompliance were NBBL (- 5.58\%). In addition, average capital fund ratio of joint venture banks during the study period hang around $14 \%$. This was higher than the minimum ratio specified by NRB. This clearly implies that joint venture banks are complying with the directive of NRB on the requirement of the capital base of commercial banks. All the selected domestic private banks h h10\%. The banks with non-compliance were LBL (5.4\%) and NCCBL (4.52\%). As transactions of the bank increases, the risk weighted assets also increases in the same manner. However, this creates banks difficulty to maintain capital fund as required by the NRB as often capital do not increase and the performance of the bank (that is, earning of profit) has major role to play to comply with the NRB requirements. As such, it is evident that the domestic private bank has been performing well enough to comply with the NRB requirement without failure at any point of time except LBL. It means domestic bank has mobilized capital from the stock market; hence, the bank has been capable to sustain the assurance of shareholders and depositors.

Asset quality: - According to the article it is obvious from the theoretical prescription that the performance of commercial banks largely depends on the quality of assets held by them, and quality of the assets relies on the financial health of their borrowers. As stated earlier, many indicators can be used to measure the quality of assets held by commercial banks. Loans are one of the major outputs provided by a bank, but as loan is a risk output, there is always an ex ante risk for a loan to eventually become non-performing. However, here, only one simple indicator - nonperforming loan ratio was used to measure the quality of assets being held by the banks. The increasing trend of these ratios shows the deteriorating quality of commercial bank assets. The article explained that in the period of 2005 to 2010, the average NPL ratio was $17.27 \%$ for NBL, 27.21\% for RBBL and $14.69 \%$ for ADBL. The ratio of NPL in the public bank was very high when compared with the joint venture banks and domestic private banks. The share of public sector banks in NPL was extremely high accounting that simply indicates the degradation of quality of loans and concentration as well. The article argued that among the JV banks, the average NPL ratio of NBBL and NCCBL were very high. These two banks were not satisfactory level. Other joint venture banks on the average were at reasonable level, but they 
are far below the aggregate percentage of non-performing assets of the commercial banks. NPL indictors show that joint venture banks were improving the quality of their assets year by year. Average NPL ratio of LBL was superior to other domestic private banks. Other domestic private banks on the average were at reasonable level. However, the banks NPL ratio was below the aggregate percentage and was in decreasing trend. The declining ratio of NPL had reflected a better quality of their assets year by year.

Management: - according to the article average IETTL of major commercial banks in Nepal for the period 2005 to 2010 of PSB (16.95\%) was found lower than that of JVB (28.72\%) and DPB (47.83\%) because management of the public sector banks was the least efficient among the sampled commercial banks. However, the joint venture and domestic private sector banks were managed the quality of loans and ensured profit. ADBL (5.31\%) management was the least efficient among the sampled public sector banks, whereas EBL (7.39\%) management was the most efficient among the joint venture banks, and NCCBL (6.51\%) was the efficient among the private sector banks.

Earning: - The net interest margin (NIM) measures how large the spread between interest revenues and interest costs that management has been able to achieve by close control over earning assets and the pursuit of the cheapest sources of funding. NIM has been treated as an extremely important measure to the bank and its minimum value for a healthy bank is considered about $4 \%$. A small change in the interest margin has a huge impact on profitability. Higher NIM is associated with profitable banks by maintaining good asset quality. The public sector banks in Nepal are entirely different from joint-venture banks and private Jha and Hui 7607 banks. The domestic banks had higher average NIM (26.65\%) than that of public banks (12.51\%) and joint venture banks (21.30\%). It means domestic banks were able to maintain good asset quality. While comparing the individual banks, the result was very different from the average values. Though ADBL is public sector bank, it was occupied first position with the highest interest margin of 5.61\% while SBL, a domestic private bank, was in the last position with lowest interest margin of $1.90 \%$. The interest margin of EBL, a joint venture bank, was $4.75 \%$ and ranked in second position. Among the all commercial banks only ADBL, NABIL, EBL and LBL were maintained minimum level. It seems the profitability of the banks in Nepal was not so satisfactory.

Liquidity: - The article stated that the credit to deposit ratio (CDR) is a major tool to examine the liquidity of a bank and measures the ratio of fund that a bank has utilized in credit out of the deposit total collected. Higher the CDR more the effectiveness of the bank to utilize the fund it collected. The article explained that the CDR of the public banks shows that their liquidity position was lower than the accepted level. However, ADBL was seemed to more efficient to utilize their funds collected as deposit. The average CDR of NBL was $39.58 \%$ while that of RBBL was $51.14 \%$ and ADBL was $111.01 \%$.

The article indicated that although there is no standard for CDR in Nepal, a ratio of $75 \%$ can be accepted to be adequate and that the CDR of the bank was quite consistent over the past five years beginning from 2005-2010. Among the six joint venture banks, the average CDR of NBBL was higher than other JV banks. In an average, the bank has been able to utilize two-third portion of the depositors fund in the form of credit. The CDR of domestic private banks was in the accepted level. The CDR of domestic private banks was higher than $75 \%$ level, which is adequate. In order to rank the banks, SBL was the first one; it has an average CDR of 93.04\%. The second position was for LBL bank with CDR equaled to $90.21 \%$, and the last position was belonged to NIBL bank with $76.01 \%$. It seems domestic private banks are efficient to utilize the funds collected as deposit.

Ranking of the commercial banks: Different commercial banks had different ranking based on each financial ratio related to ROA, ROE, CAR, NPL, IETTL, NIM and CDR. Based on the bank return on assets, the higher rank was for RBBL, which is a public sector bank, SCBL Bank, was the second, which is joint venture bank and the last position, belonged to NCCBL, a domestic private bank. Based on capital adequacy ratio SCBL was first position, LXBL was second position and last position belonged to RBBL. Based on the NPL ratio, LXBL was first position while KBL was second 
position and last position belonged to RBBL. Based on interest expenses to total loan, EBL was in the first position; NCCBL was occupied second position while the last position was for LBL. Based on net interest margin, the first position was for ADBL while EBL was occupied the second position and SBL was in the last position. Based on credit to deposit ratio, ADBL was first position, SBL was second position and last position belonged to NBL.

\section{Conclusion}

The article examined the position of profitability commercial banks in Nepal which were measured using the return on assets and return on equity. The comment here is that though financial ratios analysis compares the financial performance among commercial banks, the same bank had different ranks under the different financial ratios. It must be noted that the ROAs of public sector banks were higher than those of joint venture and domestic public banks due to having utmost total assets but the overall performance of public sector banks was not observed sound because other financial ratios including ROE, CDR, and CAR of most of the joint venture and domestic public banks were found superior.

Furthermore, high overhead costs, political interventions, poor management and low quality of collateral created continued deterioration in the financial health of the public sector banks. The values determined for the financial ratios reveal that joint venture and domestic public banks are also not so strong in Nepal to manage the possible large-scale shocks to their balance sheet. Additionally, it can be concluded from the multiple regression analysis that the capital adequacy ratio, interest expenses to total loan and net interest margin were significant but had a negative effect on ROA while nonperforming loan and credit to deposit ratio did not have any considerable effect on ROA. The capital adequacy ratio positively influenced the return on equity but the non-performing loan, credit to deposit ratio, interest expenses to total loan and net interest margin had no significant effect on ROE.

Key Performance Indicators as Tools in Measuring Commercial Banks Profitability Position: The Case of Tanzania (by Xuezhi Qin1 \& Dickson Pastory, International Journal of Business and Management; Vol. 7, No. 13; 2012, Published by Canadian Center of Science and Education Received: May 24, 2012 Accepted: June 5, 2012 Published: July 1, 2012 doi:10.5539/ijbm.v7n13p136 URL: http://dx.doi.org/10.5539/ijbm.v7n13p136

The main objective of the above article was to find out how commercial banks in Tanzania use the Key Performance Indicators as Tools in Measuring Commercial Banks Profitability Position. The article utilized panel secondary data from National bank of commerce, CRDB and National Microfinance bank in Tanzania for the period of ten years, and the hypothesis was tested to know whether there is a significant difference in terms of profitability by using ANOVA test. Finally the regression model was run to see the effects of capital adequacy, liquidity and asset quality on the profitability of commercial banks. According to the article commercial banks in Tanzania have gone into significant changes after the liberization of the banking system. The article explained that the reforms removed barriers to entry of commercial banks and supported the improvement of institutional framework and more efficiently the performance of commercial banks, with this it has affected the profitability of commercial banks and increased banking competition. Profitability of commercial banks is pro foundation for product innovation, diversification and efficiency of the commercial banks. The stability of commercial banks as whole in the economy depends on profitability level. More profitability level has tendency to absorb risks and shocks that commercial banks can face. Moreover profitability is the perquisite condition for the efficiency of commercial banks. According to the article empirical evidence has showed that the soundness of commercial banks performance depends on profitability. The article indicated that markets reforms in the subSaharan Africa has worsen the profitability of commercial banks due to high level of non-performing loans. According to the article this is contradictory to the early study of chijoriga (1997) who indicated that market liberization is essential for high level profitability of commercial banks. Profitability of commercial banks is important for the efficiency of commercial banks. According to 
the article, banks in Tanzania especially the commercial banks profitability has improved to the greatest extent and most of them are above the regulatory requirements, the greatest profitability earned by these commercial banks indicates that the internal factors has played a great role toward this profitability, Therefore to fill the above void the profitability test for giant's commercial banks in terms of market share was examined to confirm the profitability level of commercial banks. Meanwhile regression model was run in order to test profitability relationship with liquidity, asset quality and capital adequacy. Profitability in commercial banks is determined by the ability of the banks to retain capital, absorb loan losses, support future growth of assets and provide return to investors. The article found that the largest source of income to the bank is interest income from lending activity less interest paid on deposits and debt. The article stated that profitability was measured by three performance indicators which are net interest margin, return on assets and return on equity. According to the article Bank of Tanzania has set some standard measures of profitability such as: Return on equity directly reflects corporate competitiveness strength and sustainable growth. It is an important indicator in the attractiveness of the equity in the eyes of investors. Return on Asset effectively reflects corporate profitability which can be used to evaluate the performance of management in the utilization of the assets. It is calculated by dividing net income by average value of total assets over the same period. This intend to measure bank efficiency using its asset. Net interest income to average interest bearing assets; this ratio is calculated by taking total interest income less total interest expenses divided by average of the bearing assets. This intend to measure bank efficiency in using its interest bearing assets. According to the article in order to rate the profitability level of commercial banks, the bank of Tanzania use the rating approach which is in line with the Basel framework of banking and risk supervision. They are being accorded and evaluated on specific performance, in our case being profitability. According to the article the rating is based on the scale of 1 to 5 in ascending order of supervision requirements. Rating one indicates the strongest possible profit level that means the profitability level is above average, Rating two indicates satisfactory and reflects performance in terms of profitability that is average for the soundness operation of the banks, Rating three represents fair profit that is flawed to some degree, it is neither satisfactory nor unsatisfactory but it is characterized by performance below average quality, Rating 4 indicates marginal profit and the profit is below average if not changed such performance might involve into weakness or condition that could threatens the viability of the bank and finally unsatisfactory profit is the lowest profit that indicates there is a need to take remedial attention for future sustainability of the bank. The article argued that the financial ratios of individual institutions generate a warning system if ratio exceeds a predetermined critical levels or lies within a set of internal or it exceeds the boundaries of the set standards. The warning system helps to understand the stability of the commercial banks and trend of commercial banks in general. Due to the great importance of profitability for good functioning of the banking system, the article stated that there are several authors that have devoted their time in this area who studied the determinant of commercial banks profitability. The article indicated that both the internal determinant and external determinant are crucial in the profitability of commercial banks. It further analyzed the financial performance and indicated that capital adequacy, liquidity, asset quality and management are crucial in influencing the financial performance of the commercial banks. The article also investigated the determinant of commercial banks and revealed that the financial structure, banks characteristics and macroeconomic variables have potentials effect on the profitability of the commercial banks. The article's findings revealed that interest rates, government policy and bank regulation has potential impact on profitability of the commercial banks. However the article indicated that the profitability of commercial banks is being determined by the efficiency of the commercial banks itself which showed that the profitability of commercial banks has been influenced by the inflation rate, proprietary regime and core capital and that bank size and total liabilities to total asset are found to have negative impact on the profitability while GDP and inflation are found to have a negative impact on the financial performance of commercial banks. The article above examines commercial banks profitability in Tanzania for the period of ten years (2000- 
2009).The study used National Microfinance Bank (NMB), National Bank of Commerce (NBC) and CRDB as the case study. The article employed the profitability measures of commercial banks, and the evidence of performance in terms of profitability was established based on return on average asset, net interest income to average bearing assets and non-interest expenses to average assets. The findings revealed that there is no significant difference on profitability among the commercial banks, in the context of regression model it has been noted that liquidity and asset quality has positive impact in profitability with exception to the level of nonperforming loans which has a negative influence on profitability. Also capital adequacy has shown negative impact on profitability. The article confirmed the profitability of commercial banks to stable and meeting the regulatory requirement of the Bank of Tanzania (BOT).

\section{History and incorporation of ecobank transnational incorporated (ETI)}

ETI, a public limited liability company, was established as a bank holding company in 1985 under a private sector initiative spearheaded by the Federation of West African Chambers of Commerce and Industry with the support of ECOWAS. In the early 1980's the banking industry in West Africa was dominated by foreign and state-owned banks. There were hardly any commercial banks in West Africa owned and managed by the African private sector. ETI was founded with the objective of filling this vacuum. The Federation of West African Chambers of Commerce promoted and initiated a project for the creation of a private regional banking institution in West Africa. In 1984, Ecopromotions S.A. was incorporated. Its founding shareholders raised the seed capital for the feasibility studies and the promotional activities leading to the creation of ETI. In October 1985, ETI was incorporated with an authorised capital of US\$100 million. The initial paid up capital of US\$32 million was raised from over 1,500 individuals and institutions from West African countries. The largest shareholder was the ECOWAS Fund for Cooperation, Compensation and Development (ECOWAS Fund), the development finance arm of ECOWAS. A Headquarters' Agreement was signed with the government of Togo in 1985 which granted ETI the status of an international organisation with the rights and privileges necessary for it to operate as a regional institution, including the status of a non-resident financial institution. Details of the Headquarters Agreement are set out in Section 2.16. ETI commenced operations with its first subsidiary in Togo in March 1988. Today, the Ecobank Group is a full-service regional banking institution employing over 11,000 staff in over 746 branches and offices in thirty (30) west, central and east and southern African countries namely Benin, Burkina Faso, Burundi, Cape Verde, Cameroon, Central African Republic, Chad, Congo Brazzaville, Democratic Republic of Congo, Côte d'Ivoire, Gabon, The Gambia, Ghana, Guinea, Guinea Bissau, Kenya, Liberia, Malawi, Mali, Niger, Nigeria, Rwanda, Sao Tome \& Principe, Senegal, Sierra Leone, Tanzania, Togo, Uganda, Zambia and Zimbabwe. The Group's expansion plan includes the opening of new subsidiaries and branches in other Middle African countries as well as representative offices and international banking facilities in the major financial centres that have substantial trading and transaction links with Africa such as London, Paris, Dubai and Beijing. We have already opened a subsidiary in Paris, France, a representative office in Johannesburg, South Africa and Dubai, UAE. ETI has two specialised subsidiaries: Ecobank Development Corporation (EDC) and eProcess International (eProcess). EDC was incorporated with a broad mandate to develop Ecobank's investment banking and advisory businesses throughout the countries where Ecobank operates. EDC operates brokerage houses on all 3 stock exchanges in West Africa and has obtained licences to operate on the 2 stock exchanges in Central Africa: the Douala Stock Exchange in Cameroon and the Libreville Exchange in Gabon. The mandate of eProcess is to manage the Group's information technology function with a view to ultimately centralising the Group's middle and back office operations to improve efficiency, service standards and reduce costs.

\section{Background of ecobank ghana limited}

Ecobank Ghana Limited is a subsidiary of Ecobank Transnational Incorporated (ETI) a bank holding company which has currently 27 subsidiaries across Middle Africa. The Ecobank Group is in 
more countries than any other bank, making it the leading regional banking group in the middle of Africa (EBG, 2012). Ecobank Ghana Limited was incorporated in June 1989 as a private Liability company under the companies code to engage in the business of banking. The bank has grown consistently over the years to become one of the leading banks in Ghana as well as a recognized brand in the Ghanaian Banking Industry. Following its acquisition of universal banking licence in 2003, Ecobank Ghana has embarked on a strategic move from a predominantly Wholesale bank to a Retail bank. The sterling performance of the bank has been attributed to a well motivated disciplined and committed workforce. The bank uses effective training and development programmes both in-house and external to develop performance enhancing capacities of staff. Thus is coupled with a continuous review of staff functions, rotation programmes and the use of productivity based incentive package which significantly impacts positively on staff performance. Staff strength of the Bank as at 2010 was 930. Ecobank Ghana Limited operates a network of approximately 52 branches (EBG, 2012).

To become a strategic part of a World Class Pan African Banking Group. Ecobank's mission is to provide world class pan-African services to its customers while also enhancing the financial integration of Africa. In line with this Ecobank Ghana Limited seeks to create a unique African institution characterized by a determined focus on customer, employees and shareholders an absolute commitment to excellence in the financial services industry. This seeks to pursue this mission and uphold its values by applying the following principles to its business decisions and conduct.

Treat each customer as a preferred customer.

Invest in training and development of its staff.

Deliver product and service quality which exceeds customer expectations.

Develop markets and products in which it can reach and maintain competitive advantage. Deliver appropriate returns to its shareholders. Maintain high standards of ethics and compliance at all times.

\section{Personal banking}

The Ecobank Current Account opens doors to a whole new world of banking opportunities. As an Ecobank account holder, a customer can enjoy many privileges such as Ecobank Current Account which comes with the following features:

\section{Transfer and payments}

This product is for those who travel within the sub-region and need access to their funds anywhere they go. The can pay their bills or make other payments conveniently and promptly through their bank.

\section{Foreign exchange}

This product is for competitive rates for foreign currency transactions. Ecobank pride itself as market leaders in Foreign Exchange transactions and guarantees the following:

- Flexible and well structured deals

- Timely, comprehensive and assured delivery

- Competitive rates

- Highly skilled experts who provide you with special advisory services

- Some Ecobank affiliates also operate forex bureaus.

\section{International trade solutions}

International Trade involves the movement of goods and services deriving from a business transaction between a buyer in one country and a seller in another country. Ecobank provides comprehensive trade solutions to its customers using various payment methods to facilitate cross border trade through its network across Africa. Ecobank offers unique intra Africa Trade solutions, enabling its customers to settle their international trade transactions efficiently and to mitigate payment risks. Ecobank works closely with clients in reviewing key factors regarding Transaction Processing, Settlement, Financing, Risk Mitigation and Credit Enhancement. 
The bank's trade products and solutions are designed around two broad areas:

- $\quad$ Trade Finance:- Customers benefit from adequate, mitigated credit facilities.

- $\quad$ Trade Services:- Customers experience speedy turnaround and error-free processes.

\section{Trade services from ecobank}

The Ecobank cards provide both the Ecobank account holder and non-account holder with a full range of banking solutions:

- Import LCs

- Import Collections

- Customs Bonds

- Export LCs (advising and negotiating)

- Export Collections

- LC Confirmations

- Guarantees, Bid, performance and other Bonds

- Regional Trade Services in Africa

- Rapid Transfer

- International Payment Services.

\section{Regional trade services in africa}

The group provides solutions to facilitate trade in the various trade corridors and groupings across Africa; including UEMOA, ECOWAS, EAC, SADC, etc. Ecobank's Regional Trade solution enables the Exporter to obtain a payment guarantee without the need for a Letter of Credit and its related costs to the importer. Furthermore, with Ecobank on both sides of the transaction, our customers are able to benefit from a seamless end-to-end solution. Our Rapid Transfer service allows funds to be transferred across Africa on the same day, between Ecobank affiliates (subject to a \$10,000 per day limit). Regional Collections, Cross Border Funds Pooling (subject to regulations) are other available services.

\section{Africa correspondent banking and financial institutions services}

With Ecobank being present in 30 countries in Africa - more than any other bank in the world - the group's affiliates can confirm and negotiate LCs to beneficiaries in those countries, as well as manage related payments and trade confirmations from banks outside Africa.

\section{EBI SA (Ecobank Paris) LC confirmation services}

Ecobank's wholesale bank in Paris, France, speedily confirms LCs to beneficiaries, enabling a competitive end-to-end solution from the group. EBI SA's relationship with leading banks worldwide enables beneficiaries to be credited or advised of funds/trade documents. Other solutions include Structured Trade Finance and Avalized Bills Finance.

\section{Cash management}

\section{Solutions for payables}

Ecobank operates the largest network in Africa, more than any other bank in the world. The bank's payables management products are designed to improve customers payments processes and to enhance their company's operational efficiency across the countries in which Ecobank operates.

If customers are doing business in Africa, the bank can provide them with innovative and end-toend integrated cash management solutions to suit their specific needs in all the countries in which we operate.

The bank's products specialists and Account managers will work closely with customers to understand their business. They will also customize a range of innovative, value-enhancing solutions to optimize payment processes for all customers' business needs across Sub-Saharan Africa. 
Texila International Journal of Management

Volume 2, Issue 2, Dec 2016

\section{Electronic bulk supplier payments}

Utilize a secure environment for customers' large payments to suppliers (vendors), and for payroll. Payments information is securely received from the bank's customers either through an ERP account payables system or agreed data format. The bank processes and authenticates customers' transactions electronically and credit beneficiaries swiftly, enabling Straight-Thru-Process (STP) benefits to customers. These solutions are available via our Ecobank Corporate Internet Banking and other Ecobank systems.

\section{Customer on-site payment services}

Teller and cashiering solutions are available at agreed customer locations. Cheque encashment, cash disbursement, wage packaging and other solutions are available on request.

\section{Mass payment services}

For large payments such as Dividend credits, Large Salary Runs, IPO Cheque Refunds, Student Loan credits, Insurance payments etc, Ecobank will work with clients to produce tailored solutions to required standards of efficiency.

\section{EFT / RTGS / SWIFT Services}

In many countries, the domestic and third party payments require specialized Electronic Funds Transfers (EFT), Real Time Gross Settlement (RTGS) payments for high value transactions and SWIFT payments. Ecobank's payment processes enable speedy processing and beneficiary confirmation via Ecobank Corporate Internet Banking.

\section{Over-the-counter payment services}

This service is designed to enable companies to make payments through the bank to be received directly by beneficiaries at the counters of Ecobank branches. Payment details are conveyed to a designated Ecobank branch where payment will be received. Payment can be either in cash or by cheque. Ecobank provides a comprehensive corporate payment platform which enables clients to send beneficiary details to the bank in a secure manner. This service eliminates the need for tellers in your company.

\section{Company payroll services}

Ecobank can offer unique payroll processing services to companies. Gross salary data of employees sent to Ecobank is swiftly processed to net figure level after the deduction of all statutory obligations. Various reports will be generated and sent to the companies for approval, before actual payments to beneficiary accounts are confirmed. This service is available in a select number of countries.

\section{Cash delivery services}

Specialized cash delivery services at agreed locations and frequency is available in several countries in which Ecobank operates.

\section{Card and ATM services}

Ecobank has invested in leading-edge technology and operates a group switch underpinning a Regional Card issuance in the countries in which it operates. The card can be used to withdraw cash in different countries and currencies. The Regional Card usage has now been extended to South Africa where holders can withdraw cash from over 1,860 ATMs operated by Nedbank, Ecobank's alliance partner in South Africa. A range of ATMs in several countries also provide additional services to Ecobank customers. These services complement the bank's corporate customers by providing efficient services to organizations and companies. 


\section{Solutions for receivables}

The bank's Receivables Management products and solutions are designed to accelerate customers' cash inflows and meet their corporate cash management needs across the countries in which the bank operates. The bank can provide customers with innovative, end-to-end integrated cash management solutions to suit their specific needs. Obtain faster access to customers' funds with an efficient network in the bank's countries. The bank's products staff and Account Managers will work with customers to understand their business, workflow and to customize a range of innovative, valueenhancing solutions for enhanced productivity and financial benefit to customers' organization. The service is specially designed to meet the needs of businesses across the Sub-Saharan Africa region. The bank streamline customers collections processes and enable them to extract additional liquidity in their working capital cycle; from when orders are placed to cash realization. Cash in Transit Services (CIT).

\section{Post-dated cheque collection (PDC)}

The bank handles the complete life cycle of the Post-Dated Cheques until they are realized. All the post-dated cheque management activities such as maintaining inventories, retrieval and depositing cheque for payment, re-presentation where possible and exception handling, such as stop payment requests, will be handled by the bank on customers' behalf. The bank guarantees safety of the postdated cheques, timely presentation and credit to account as well as real time update of account information.

\section{In-branch collections}

The bank's branches serve as cash and cheque collection locations enabling customers / consumers to make payment directly into their account with real time online transfer of information to their offices. Ecobank processes these collections efficiently to avoid any reconciliation issues. As a result of this solution, Customers Company acquires a wider reach across the African regions. Ecobank has currently over 750 branches and business offices across 30 African countries. This service is mostly suitable for tax collections, bill collections, distributor collections, school fees collections, investment funds collections and IPO collections.

\section{Teller implant services}

The bank will provide an officer to directly offer cashiering services to your customers in your office. The service facilitates cash, cheques and card transactions, thereby providing multiple deposit options to your customers. The bank will ensure that all funds collected on behalf of your company are lodged into your account on a daily basis with on-line access to account information.

\section{Mass collections}

The bank's Mass Collection solutions are particularly useful for utilities, cable companies, revenue authorities and clients with large volume of deposit requirements. Utilizing Ecobank Collections platforms, Receivables Management is enhanced for these large corporates requiring collections solutions. The bank provides data enrichment, with many customer defined fields captured with each deposit. Details like Unique reference numbers, ID numbers like Passport no, Location details of deposit - City, Region, Province etc are captured. Depending on client and country, the bank is able to interface this solution to customer account receivable system and enable immediate reconciliation and payment confirmation of customers' deposits. Customizable reports are available to clients for enhanced control over their working capital.

\section{Merchant POS acquiring services}

Leveraging Ecobank's massive investment in technology, Ecobank has a pioneering Group switch for our cards and payments products. Ecobank's Regional Card enables ATM and POS transactions in 
the countries in which we operate and also a unique offering at Nedbank ATMs in South Africa. The bank's Merchant Point of Sale (POS) service enables merchants, stores and corporates to offer POS card acquiring. Thus customer's sales are speedily credited to your account as our POS can accept Ecobank Regional cards, Mastercard and Visa depending on the country and location.

\section{Ecobank's philosophy}

The bank believes that its success depends for the most part on its ability to maintain a diverse, resourceful and dynamic workforce to serve its customers. The bank has a strong policy in sourcing, attracting, developing and retaining the best talents. Accordingly Ecobank continuously strives to:

- Recruit, develop and retain a highly-motivated workforce nurtured by an enabling environment.

- Provide an environment that identifies, encourages, and rewards excellence, innovation and quality customer service.

- Provide the climate and resources that enable staff to advance on merit as far as their talents and competence will take them, without regard to gender, race, religion, color, age, national origin, marital status, physical challenges and/or disability status.

- Offer compensation and benefits that are fair, competitive and linked to performance.

- Maintain avenues for open communication to facilitate creativity and synergy in developing solutions to work place challenges.

- Promote work-life balance initiatives aimed at helping our employees maintain a healthy balance between their work pressures and family/domestic responsibilities.

- Promote diversity and involvement/inclusion in all our pursuits.

- Develop a broad and deep pool of talented professionals with the skills, experience and mindset to operate across different markets and cultures within and beyond the African continent.

\section{Performance-based compensation}

Ecobank provides a world class multi-cultural and multilingual high performing environment that allows people to excel and reach their potential. Ecobank is committed to employing and retaining the best talents in Africa. There is no other more exciting place to build a career than Ecobank. To help prepare employees for the right job Ecobank has partnered with The Gallup Organization to identify the best talent globally.

Ecobank offers one of the best competitive benefits packages in Africa. Its bonus scheme and many other short and long term incentive programs form an important part of its performance-driven compensation culture.

Ecobank maintains a talent based recruitment and selection system and does not discriminate on the basis of gender, race, sexual orientation, religion, color, age, national origin, marital status, ancestry, physical challenges and/or disability status. The bank affirms in policy and practice to support and promotes the concept of equal employment opportunity and affirmative action in line with all applicable laws wherever it maintains presence. Candidates must possess the right to work wherever job openings for which they are most suited occurs. It is not the practice of Ecobank to sponsor or process work permits for candidates.

\section{Ecobank policy on key performance indicators}

The bank could not make available to the researcher its policy on the bank's Key Performance Indicators and it uses it to measure its financial performance. The reason given was based on the fact that is inaccessible on confidential grounds. However, the researcher gave appropriate recommendations to this effect. 


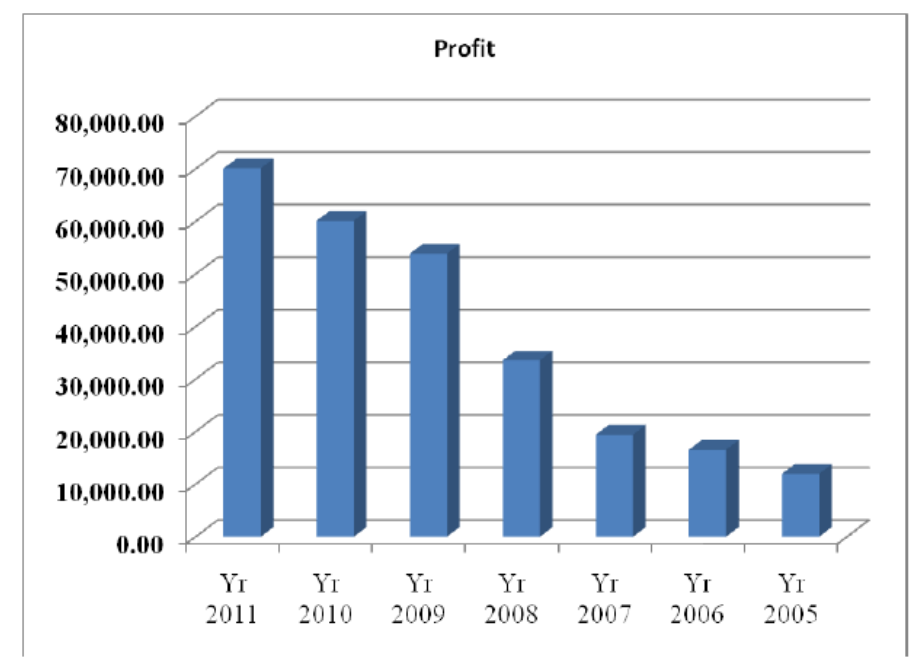

Figure 1: Profitability Trend from 2005 to 2011(GHS’000)

Source: Annual Reports of Ecobank Ghana (2005-2011)

Figure 1 shows an increasing profitability trend from 2005 to 2006 with a slight decrease in 2007. Return on assets increased by $5.14 \%$ from $1.36 \%$ in 2005 to $1.43 \%$ in 2006 before slightly falling to $1.40 \%$ in 2007. It is believed that the banks' profitability remained favourable during 2005-2006 due to strong asset growth as the total assets grew from GHS319,567 billion in 2005 to GHS431,861 billion in 2006 registering an increase of $25.3 \%$. Loans and advances were the main contributors to the increase in assets mainly due to increase in mortgage loans. The higher ratios indicate a better prospective as the high net interest margin was feeding through greater net income thus boosting ROA and ROE.

However, at the onset of the economic downturn bank performance deteriorated slightly. ROA decreased from $1.40 \%$ for the year 2007 to $1.17 \%$ in 2008 before finally settling on a low $0.80 \%$ for the year 2009, a consequence of the global financial crisis and a slowing down in the domestic economy. The downward trend is also reflected in the ROE, which decreased from $24.01 \%$ in 2007 to $20.33 \%$ in 2008 before drastically decreasing to $13.65 \%$ in 2009 , reflecting a decline of $35.56 \%$. The downward trend is attributable to a decrease in loans and advances to customers as well as increased credit impairments owing to defaults which negatively impacted profitability.

The trend reflected by ROA and ROE is also reflected in the cost to income ratio, which improved by $9.2 \%$ from 60.93 in 2005 to 55.32 in 2006 indicating better efficiency and profitability performance. The ratio continued to show signs of improvement, it strengthened by $6.79 \%$ from 51.53 in 2007 to 48.03 in 2008.

The steady improvements in cost to income are mainly ascribed to increasing net income reported by the bank which rose by 63\% from GHS24,789,800 in 2005 to GHS31,724,000 in 2006 consequent of the lower loan loss provisions and relatively lower operating expenses experienced by the large banks during that period. The decline in the C/I ratio is as a result of cost efficiency levels which Ncube (2009) in his study of efficiency levels in South African banks found to have significantly improved. However, from 2008 the C/I ratio continued to fall at a decreasing rate and eventually increased to 49.65 in 2009.

\section{Liquidity performance}

Liquidity performance measures the ability to meet financial obligations as they become due and is crucial to the sustained viability of banking institutions. What began as credit concerns for the US sub-prime market developed into concerns in global credit markets with unknown financial exposures and potential losses. The resultant uncertainty made financial market participants exceedingly risk 
Texila International Journal of Management

Volume 2, Issue 2, Dec 2016

averse, such that they were unwilling to invest in any markets or financial instruments other than 'safe havens'. This severely reduced the levels of liquidity in the global financial markets (SARB, 2009).

Ghana was not immune to such developments and this is reflected in the liquidity ratios. Ghanaian banks rely on customer's deposits and their current balances with the Bank of Ghana Reserve for their liquidity. These banks are required to hold an average daily amount of liquid assets that shall not be less than $5 \%$ of adjusted liabilities. Figure 2 shows the liquidity trend in terms of average net loan to total assets ratio (NLTA), net loan to deposit and short term borrowing ratio (NLDST), and liquid assets to deposits and short term borrowing ratio (LADST).

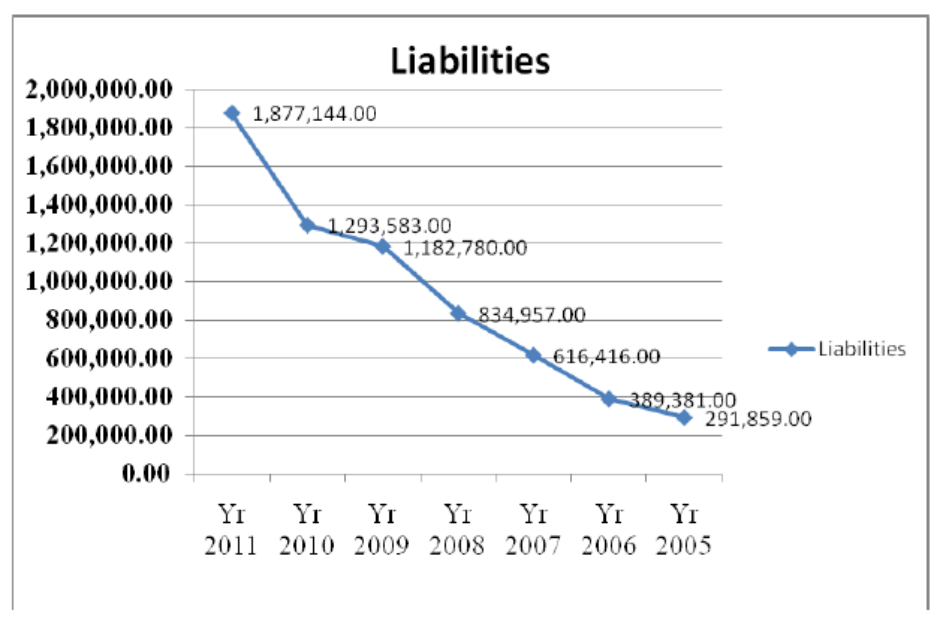

Figure 2: Liquidity Trend from 2005 to 2011(GHS’000)

Source: Annual Reports of Ecobank Ghana (2005-2011)

In as much as the ratio of net loans to total assets does not directly measure liquidity, it gives an indication of how much of the bank assets are tied into illiquid loans. From the trend displayed by Figure 3, NLTA increased by 2.84\% from 73.00 in 2005 to 75.08 in 2006 and increased again to 76.48 in 2007 when favourable economic conditions increased the demand for loans from businesses and allowed Ecobank Ghana to grow its loan portfolios. Loans to customers increased by $30 \%$ from GHS117,525,000, in 2005 to GHS848,459,000 in 2011 while total assets increased from GHS319,567,000 in 2005 to GHS2,128,006 in 2011.

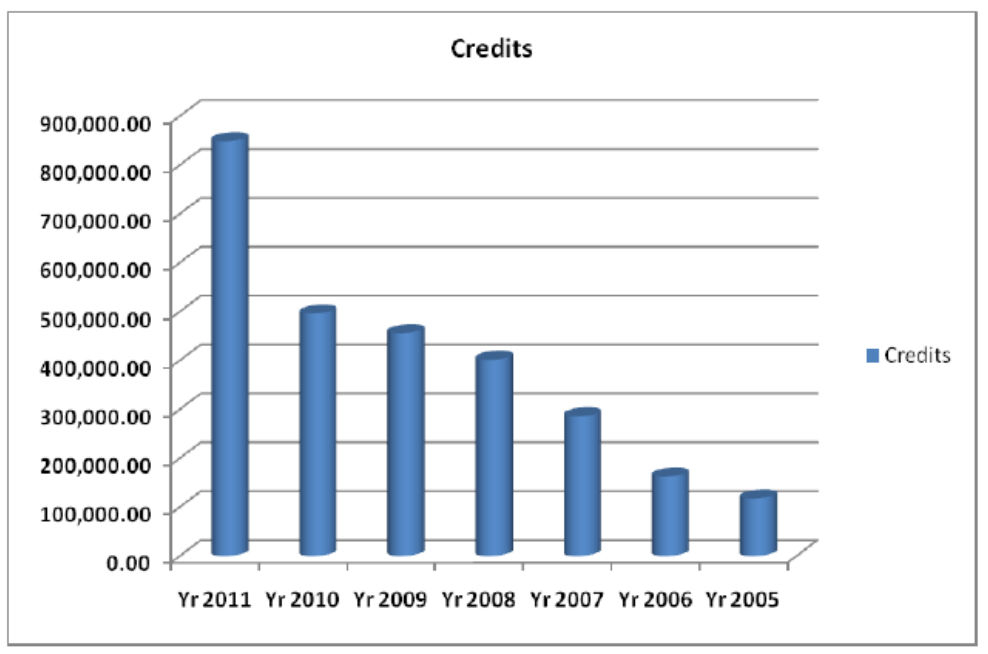

Figure 3: Credit Trend from 2005 to 2011(GHS’000)

Source: Annual Reports of Ecobank Ghana (2005-2011) 
In 2008 NLTA increased to 72.94 before finally increasing marginally again to 73.99 in 2009. The change in the trend signifies the slowing down in loans to customers and a continued increase in impaired loans leading to a decrease in net loans and in total assets which consequently decreased by $4.78 \%$ to GHS2.673 billion at the end of 2009. Generally, a higher NLTA may indicate possible liquidity problems for the bank in a tight credit market in the face of a large deposit withdrawal or in case of unexpected withdrawals. However, the increase in NLTA for the bank did not pose any liquidity problems as the bank could still access the cash reserves that they held in excess of the minimum requirement with the reserve bank (BoG).

The LADST ratio has been gradually falling for the period under review indicating reduced liquidity for the banks. The ratio decrease by $14.56 \%$ from 18.06 in 2005 to 15.43 in 2006 indicating a fall in the amount of customer and short term funds that could be met if they were suddenly withdrawn. The ratio however slightly increased by $2.03 \%$ in 2008 as the amount of liquid assets held by the banks increased by $20 \%$ during 2009 as the bank increased its investments in instruments qualifying as liquid assets. The ratio then decreased from 15.06 to 13.40 in 2009 indicating a further deterioration in liquidity. Therefore in as much as the bank has been increasing their percentage of liquid assets that mainly consist of current accounts/reserves with the BoG and other banks, customer deposits and short term funding have also been increasing such that the overall trend continued to show reduced levels of liquidity.

NLDST followed a similar trend increasing by $2.16 \%$ from 88.02 in 2005 to 89.93 in 2006 and subsequently increasing by $8.55 \%$ to 97.62 in 2007 . The increasing trend indicate deteriorating liquidity in the banking sector as more and more assets, customer deposits and short term funding are tied into loans which are classified as illiquid assets. The liquidity of the banks contracted most between the years 2006-2007 when the banks were aggressively increasing their loan portfolios.

The variation in the ratio from 2007 onwards is ascribed to changes in both loans to customers and changes in deposit and short term funding. The banks tightened lending standards later in 2008 in response to the global financial crisis such that credit expansion slipped by $2.6 \%$ from GHS8.42 billion in 2008 to GHS7.94 billion in 2009 eventually reaching very low levels and zero growth by the end of the year. The lower rate may also be attributed to a tighter monetary policy stance and the implementation of the stringent risk based lending criteria by the banks as a result of the introduction of the National Regulatory Policies in 2007. While the bank loans and advances contracted during 2009, the contraction in credit extension had both demand-side and supply-side elements (SARB, 2009). On the demand side, it would appear that households continued to be reluctant to incur more debt leading to a fall in demand for loans, while on the supply side lending standards have remained tight and led to the slowing down in the growth of loans and advances to customers. Financial stability issues lie at the profitability-liquidity nexus therefore a decline in liquidity is associated with an increase in profitability, since low liquidity means larger percentage of assets and total deposits are tied with loans. Under normal circumstances rapid loan growth tend to result in higher returns and higher risks. However, Saunders and Cornett (2006) argue that rapid growth in assets (loans) than in deposits is indicative of banks using borrowed funds excessively. This seems to highlight the position of the bank under study. There has been a growing trend in loans and advances to customers; however, this increase has not been met by an equal increase in customer deposits. This may then mean that the bank has been turning to purchased liquidity in the form of money market instruments to fund the increase in loans. However, this remains uncertain as the data contained in Bankscope is not adequate to be able to back up the information with detailed ratios. Furthermore, a closer inspection of the balance sheets shows that retail deposits represent only about $25 \%$ of total deposits in the Ghanaian banking system, while deposits with less than one year maturity represent close to $80 \%$ of total deposits (IMF, 2008).It is therefore worth noting that as a result of the above mentioned issues concerning the composition of the deposits, the Ghanaian banking system faces long-standing structural risks rooted in the sector's reliance on short-term wholesale deposits. The IMF has recommended that the BoG explore ways to reduce the risks associated with the banks' reliance on 
short term wholesale deposits. One of the recommendations is implementing a deposit insurance system to counter such risks and provide the added benefit of inducing household saving to migrate from unguaranteed liquid financial instruments to competing bank deposits, thus strengthening the retail base of banks.

\section{Asset Credit Quality (Credit Performance)}

Credit performance is concerned with the examination of the risk associated with a bank's asset portfolio. Figure 3 shows a fairly stable trend in the loan reserve to gross loans ratio between 2005 and 2007. However, 2008-2009 shows a significant deterioration in the credit quality. The ratio registered a decline of $12 \%$ from 1.83 to 1.61 during $2005-2006$ before slightly increasing from 1.61 to 1.68 in 2007. The slight improvement was due to continued growth in loans to customers as well as growth in non performing loans which continued on a downward trend.



Figure 4: Total Assets from 2005 to 2011(GHS’000)

Source: Annual Reports of Ecobank Ghana (2005-2011)

The loan portfolio deteriorated in 2008-2009 as the ratio increased by $8.33 \%$ from 1.92 in 2008 to 2.08 in 2009. Credit risk ratios increased during 2008 indicating the deterioration of the quality of the loan portfolio as compared to 2005. For the period 2008 to 2009 nonperforming loans and advances increased from 2.8\% in July 2008, to $5.5 \%$ in August 2009, as a result of the crisis and the period was also marked by an increase in credit losses in line with the tougher market conditions. This is because the bank was more exposed to increased credit risk as risky loans given during the 2005-2011 period began to go bad and the banks reported higher charge off or additional provision for loan losses. Hence the bank was facing increased credit risk, especially in their home loan portfolios, in the face of record household indebtedness and a mounting debt service burden.

Overall, although risk appetites were adjusted in line with challenging economic conditions and caution was exercised with regard to lending, the operating environment continued to be under pressure during 2009 as evidenced by increased credit impairments and resultant lower profitability levels. This resulted in the quality of the loan portfolio sharply deteriorating during 2008- 2009.

\section{The importance of key financial indicators to banks}

According to the results obtained from the interview conducted with the head of finance Key performance indicators (KPIs) are "critical success factors" that are crucial for the continued success of a business or any organization. The benefits of KPIs are twofold: a means for continuous improvement and keeping in line with group strategies and targets, and a prerequisite for being able to benchmark against other competitors. A good set of KPIs is a successful way to help managers and staff prioritise their daily work. KPIs enable an ideal overview for management without having to 
have one's nose in the details. With the right KPIs, one can focus on one's own tasks instead of meddling with those of subordinates. The main benefit of keeping key performance indicators is that it keeps the entire organization working toward common goals. People work only on meaningful projects and eliminate useless activity. The bank is also more likely to accomplish its objectives if it has clearly defined objectives linked to Key Performance Indicators. This is meant as an exhaustive or complete list of the financial details an investor needs to consider, when contemplating a bank investment.

\section{Financial strategies for improving bank performance}

The interview results obtained indicate that the strategy of the bank is to position the Bank effectively within a more volatile, uncertain and competitive environment, whilst remaining focused on serving the primary needs of its clients. It was shown that the Bank has a unique position in Ghana and Africa and remain relevant to all its Regional Member Countries. To do so it must be more effective and equipped with appropriate instruments and resources. An effective strategy is therefore the bank's a framework, not a blueprint. Within a clear set of priorities, the Bank is able to respond to changing needs and circumstances. The bank is judged by its results: the contribution it makes to development in particular by promoting equitable growth and economic integration, and through them, wider opportunities. The aim remains to become the preferred partner in in Ghana and Africa, providing quality investment and advice. According to the head of finance, the Bank has built and will maintain a strong balance sheet and credit rating and that the bank uses more fully the comparative advantages of its integrated structure, bringing together sovereign, non-sovereign, and concessional resources to meet the particular needs of customers. He stated that progress is closely monitored and regularly reported.

\section{Research findings}

The bank applies dividend payment policy and that though dividends are paid out of profits; it is basically dependent on cash availability.

It was revealed that the best performance indicators are those that could provide accurate assessment of the bank's Profitability Performance, Liquidity performance and Asset Credit Quality. The key financial indicators for assessing the financial performance of Ecobank Ghana Limited are as follows: Profitability which is measured using the following criteria: Return on Assets (ROA), Return on Equity (ROE) and Cost to Income Ratio (CIR).Liquidity performance is measured using Liquid assets to deposit-borrowing ratio (LADST), Net Loans to total asset ratio (NLTA), Net loans to deposit and borrowing (NLDST). Asset Credit Quality (Credit Performance) is measured using Loan loss reserve to gross loans (LRGL). Key performance indicators (KPIs) are "critical success factors" that are crucial for the continued success of a business or any organization. The main benefit of keeping key performance indicators is that it keeps the entire organization working toward common goals. The bank is also more likely to accomplish its objectives if it has clearly defined objectives linked to Key Performance Indicators. The strategy of the bank is to position the Bank effectively within a more volatile, uncertain and competitive environment, whilst remaining focused on serving the primary needs of its clients. The Bank has built and will maintain a strong balance sheet and credit rating and that the bank uses more fully the comparative advantages of its integrated structure, bringing together sovereign, non-sovereign, and concessional resources to meet the particular needs of customers. According to the findings the best performance indicators are those that could provide accurate assessment of the bank's Profitability Performance, Liquidity performance and Asset Credit Quality. These are discussed below:

\section{Profitability performance}

The most common measure of bank performance is profitability. Profitability is measured using the following criteria: 
Return on Assets $(\mathrm{ROA})=$ net profit/total assets shows the ability of management to acquire deposits at a reasonable cost and invest them in profitable investments (Ahmed, 2009). This ratio indicates how much net income is generated per GHS (Ghana Cedis) of assets. The higher the ROA, the more the profitable the bank. Return on Equity $(\mathrm{ROE})=$ net profit/ total equity. ROE is the most important indicator of a bank's profitability and growth potential. It is the rate of return to shareholders or the percentage return on each GHC of equity invested in the bank. Cost to Income Ratio $(\mathrm{C} / \mathrm{I})=$ total cost /total income measures the income generated per GHC cost. That is how expensive it is for the bank to produce a unit of output. The lower the C/I ratio, the better the performance of the bank.

\section{Liquidity performance}

Liquidity in banks is very important due to the fact that it is the ability of banks to meet their current obligations as and when these become due. In banks this is very vital for their survival in the market. In this respect, the impacts of NPLs on liquidity need to be cautiously analyzed to ensure quality of liquidity. The implication is that as the bank's main business is to accept deposits from depositors and lend them to borrowers, more deposits were made in the ensuing financial year. For this reason, to earn more returns from the deposits the bank lent more credits to borrowers which resulted into increasing NPLs over the years under consideration. It must also be noted that to a large degree the level of deposits is driven more by the independent decisions of bank customers. With this relationship in mind, the level of liquid assets required by a bank will depend on how stable the deposit and funding base is as well as the stability of the demand for funds. If there is stability in funding and demand for loan funds, a lower level of liquid assets is resulted. Increasing NPLs not only critically affect the liquidity of financial institutions but also force the bank to maintain more liquid assets thereby increasing the cost.

Liquidity indicates the ability of the bank to meet its financial obligations in a timely and effective manner. Samad (2004:36) states that "liquidity is the life and blood of a commercial bank". Financial liabilities are attracted through retail and wholesale distribution channels. Retail generated funding is considered less interest elastic and more reliable than deposits attracted from wholesale distribution channels (Thygerson, 1995).

Liquidity performance is measured using Liquid assets to deposit-borrowing ratio (LADST), Net Loans to total asset ratio (NLTA), Net loans to deposit and borrowing (NLDST). Liquid assets to deposit-borrowing ratio (LADST) = liquid asset/customer deposit and short term borrowed funds. This ratio indicates the percentage of short term obligations that could be met with the bank's liquid assets in the case of sudden withdrawals. Net Loans to total asset ratio (NLTA) = Net loans/total assets NLTA measures the percentage of assets that is tied up in loans. The higher the ratio, the less liquid the bank is.Net loans to deposit and borrowing $($ NLDST) $=$ Net loans/total deposits and short term borrowings. This ratio indicates the percentage of the total deposits locked into non-liquid assets. A high figure denotes lower liquidity.

\section{Asset credit quality (credit performance)}

It was revealed that the bank's Asset Credit Quality (Credit Performance) is measured using Loan loss reserve to gross loans (LRGL). While it is expected that banks would bear some bad loans and losses in their lending activities, one of the key objectives of the bank is to minimize such losses (Casu et al, 2006). Credit performance evaluates the risks associated with the bank's asset portfolio i.e. the quality of loans issued by the bank. Several ratios can be used for measuring credit quality however, not all information on the loans is always available. Loan loss reserve to gross loans $(\mathrm{LRGL})=$ Loan loss reserve/gross loans. This ratio indicates the proportion of the total portfolio that has been set aside but not charged off. It is a reserve for losses expressed as a percentage of total loans. 


\section{Importance of KPIs to the bank}

According to the results obtained from the interview conducted with the head of finance Key performance indicators (KPIs) are "critical success factors" that are crucial for the continued success of a business or any organization. For many banks, loan growth is as important as revenue growth to most industrial companies. The trouble with loan growth is that it is very difficult for an outside investor to evaluate the quality of the borrowers that the bank is serving. Above-average loan growth can mean that the bank has targeted attractive new markets, or has a low-cost capital base that allows it to charge less for its loans. On the other hand, above average loan growth can also mean that a bank is pricing its money more cheaply, loosening its credit standards or somehow encouraging borrowers to move over their business. As previously discussed, deposits are the most common, and almost always the cheapest, source of loanable funds for banks. Accordingly, deposit growth gives investors a sense of how much lending a bank can do. There are some important factors to consider with this number. First, the cost of those funds is important; a bank that grows its deposits by offering more generous rates is not in the same competitive position as a bank that can produce the same deposit growth at lower rates. Also, deposit growth has to be analyzed in the context of loan growth and the bank management's plans for loan growth. Accumulating deposits, particularly at higher rates, is actually bad for earnings if the bank cannot profitably deploy those funds. The loan/deposit ratio helps assess a bank's liquidity, and by extension, the aggressiveness of the bank's management. If the loan/deposit ratio is too high, the bank could be vulnerable to any sudden adverse changes in its deposit base. Conversely, if the loan/deposit ratio is too low, the bank is holding on to unproductive capital and earning less than it should. Returns on equity and assets are well-established metrics long used in fundamental analysis across a wide range of industries. Return on equity is especially useful in the valuation of banks, as traditional cash flow models can be very difficult to construct for financial companies, and return-on-equity models can offer similar information. The importance of credit quality ratios is somewhat self-explanatory. If a bank's credit quality is in decline because of nonperforming loans and assets and/or charge-offs increases, the bank's earnings and capital may be at risk. A non-performing loan is a loan where payments of interest or principal are overdue by 90 days or more, and it is typically presented as a percentage of outstanding loans. Net charge-offs represent the difference in loans that are written off as unlikely to be recovered (gross charge-offs) and any recoveries in previously written-off loans. Based on the critical analysis of the data and findings thereafter revealed, the following recommendations are made: It is recommended that in choosing the right Key Performance Indicators (KPIs), it must be reliant upon having a good understanding of what is important to the bank. KPI should follow the SMART criteria. This means the measure should have a Specific purpose for the business, should be Measurable to really get a value of the KPI, the defined norms should have to be Achievable, the improvement of a KPI has to be Relevant to the success of the organization, and finally it must be Time phased, which means the value or outcomes are shown for a predefined and relevant period. Management of the bank should ensure that Key Performance Indicators are aligned with the specific goals and objectives of the bank. Key performance indicators must be quantifiable. The goal must be stated in concise terms and capable of being measured. A time frame must also be established for all key performance indicators, with key checkpoints at various intervals. The current pattern of financial analysis in the bank should be divided into two categories: (a) financial analysis during project identification, and (b) financial analysis during project preparation. In both cases, financial statements of the bank must be analysed and financial projections prepared. The present analytical framework must however provide a common style of analysis across the bank operations. Several improvements are recommended. In order for the financial analysts to diagnose the condition of the bank through the financial statements, a better framework for the analysis should be prepared, based on the material presented in the framework. The framework should use five different but inter-related measures of the financial health of the bank thus: earnings performance analysis, liquidity analysis, capital adequacy analysis and asset quality analysis. The current presentation of financial statements used in preparation of reports included cash flow 
statement. By introducing the cash flow statement, it will be easier for analysts to examine liquidity issues, and deteriorating financial condition of bank in situations where the continued operation of the entity is only possible by resorting to debt financing or government financing. Standardization in the assumption variables that analyst can choose in preparing financial projections of the bank. While bank's operations cover different sectors of the economy, the quality of analysis can be improved by standardizing the list of assumptions.

- The bank should develop common set of ratios: To standardize the analysis, a common set of core ratios could be prepared.

- Finally and most importantly, it is recommended that bank must make available its policy on Key Performance Indicators and it uses it to measure its financial performance. This is because, such an academic endeavour such as this sought to critically analysis of key financial performance indicators in the banking industry. Therefore, since the performance evaluation of bank is a difficult task and one of the main reasons for this difficulty is the complexity inherent in the variety of aspects to be considered in the evaluation, and the multiple and conflicting interests of the different investor-stakeholders, this study provides a Key or Tool used to measure the bank's financial performance so as to improve performance through performance measurement and management.

\section{Conclusion}

This study sought to critically explore the key financial indicators in the banking industry. In order to achieve this objective, the study provided an overview of the Ghanaian Banking sector as well in depth discussion on key performance indicators. Reviews of relevant literatures on key performance indicators in measuring bank performance were presented. The study made use of secondary data in exploring the key financial indicators in the Ghanaian banking sector. The secondary data were obtained basically from published annual reports of Ecobank Ghana Limited. The annual data for Ecobank Ghana Limited during (2005-2011) were used for calculating key financial ratios in order to assess the performance of the bank. This study measured the performance of Ecobank Ghana Limited over the period 2005-2009. The results indicate that the overall bank performance in terms of profitability, liquidity, and credit quality has been improving since 2005 up to and including 2007. The Bank increased the size of their loan portfolios during the period under review. Although the bank aggressively increased its loan portfolios, sound and effective credit risk management policies have been in place so that the lending behaviour could still be contained. This is reflected in the downward trend in nonperforming loans. This is exacerbated by the bank's dependence on wholesale markets and the fact that deposits with less than one year maturity represent close to $80 \%$ of total deposits. Despite these alarming features Ecobank Ghana Limited has managed to continue with its normal day to day business during this time of keen competition.

It now obvious from this study that the key financial indicators for assessing the financial performance of Ecobank Ghana Limited are as follows:

- Profitability which is measured using the following criteria: Return on Assets (ROA), Return on Equity (ROE) and Cost to Income Ratio (CIR).

- Liquidity performance is measured using Liquid assets to deposit-borrowing ratio (LADST), Net Loans to total asset ratio (NLTA), Net loans to deposit and borrowing (NLDST).

- Asset Credit Quality (Credit Performance) is measured using Loan loss reserve to gross loans (LRGL).

Based on these facts, it can be stated that key financial indicators in the banking industry are metrics used to quantify objectives. They are measured regularly to reflect and manage the strategic performance of an organization in this case Ecobank Ghana Limited. The importance for a KPI is that it makes it easy to find and collect the information and, above all, to interpret what activities must be performed to improve the performance. It is therefore concluded that Key Performance Indicators 
(KPIs) are "critical success factors" that are crucial for the continued success of a business or any organization.

\section{References}

[1] Alam HM, Raza A, Akram M (2011). A financial performance comparison of public vs private banks: The case of commercial banking sector of Pakistan. Int. J. Bus. Soc. Sci., 2(11): 56-64.

[2] Amandeep (1990): "Profits and Profitability of Indian Nationalized Banks," Ph.D Thesis, Punjab University, Chandigarh.

[3] Avkiran NK (1995). Developing an instrument to measure customer service quality in branch banking. Int. J. Banks Mark., 12(6): 10-18.

[4] Bakar N, Tahir IM (2009). Applying multiple linear regression and neural network to predict bank performance. Int. Bus. Res., 2 (4):176-183.

[5] Balasundaram Nimalathasan (2009) Determinants of Key Performance Indicators (KPIS) Of Private Sector Banks In Srilanka: An Application Of Exploratory Factor Analysis Department of Commerce, University of Jaffna, Jaffna, SriLanka Fascicle of the Faculty of Economics and Public Administration Vol. 9, No. 2(10), 2009 [6] Baral JK (2005). Health check-up of commercial banks in the framework of CAMEL: A case study of joint venture banks in Nepal, J. Nepalese Bus. Stud., 2(1): 41-55

[7] Balsley, H.L. (1970). Quantitative research methods for business and economics. New York: Random House.

[8] Berger, A.N. and Humphrey, D.B. (1997). Efficiency of financial institutions: international survey and directions for future research. European Journal of Operational Research, Vol 98, pp.175-212.

[9] Cassell, C., \& Symon, G. (1994). Qualitative research in work contexts. In C. Cassell, \& G. Symon (Eds.), Qualitative methods in organizational research (pp. 1-13). Thousand Oaks, CA: Sage Publications.

[10]Casu, B., Molyneux, P. And Girardone, C. (2006). Introduction to Banking, Prentice Hall/ Financial Times, London.

[11]Cronje, T. (2007). Assessing the relative efficiency management of South African banks. Management Dynamics 16 pp 11-23.

[12] Drake, L. (2001). Efficiency and productivity change in UK banking. Applied Financial Economics 11, pp 557-571.

[13] Economic Survey (2008). Ministry of Finance, Government of Nepal.

[14]Elyor S (2009). Factors affecting the performance of foreign banks in Malaysia. Master's degree Thesis, Univ. Utara Malaysia.

[15] Frankfort-Nachmias, C., \& Nachmias, D. (1992). Research methods in the social sciences (4th ed.). New York: St. Martin's Press.

[16] Gopinathan T (2009). Financial ratio analysis for performance check. http://suite101.com/article/financialratio-analysis-for-performancecheck- a109025.

[17]Halkos, G. and Salamouris, D. (2004). Efficiency measurement of the Greek commercial banks with the use of financial ratios: a data envelope analysis approach. Management Accounting Research 15 (2), pp 201- 224.

[18] Ho C, Zhu D (2004). Performance measurement of Taiwan commercial banks. Int. J. Product. Perform. Manag., 53(5): 425-434.

[19] Kealey, D.J., \& Protheroe, D.R. (1996). The effectiveness of cross-cultural training for expatriates: An assessment of the literature on the issue. International Journal of Intercultural Relations, 20(2), 141-165.

[20]Kiyota, H. (2009).Efficiency of Commercial Banks in Sub-Saharan Africa: A Comparative Analysis of Domestic and Foreign Banks. A paper prepared for the CSAE conference 2009 on "Economic Development in Africa” held at the University of Oxford.

[21] Koasmidou K (2008). The determinants of banks' profits in Greece during the period of EU financial integration. Manag. Financ., 34(3): 146-159.

[22] Lacewell, S., K. (2003). Do Efficient Institutions Score Well Using Ratio Analysis? An Examination Of Commercial Banks in The 1990s. Journal of Commercial Banking and Finance 2, pp 17-33. 
Texila International Journal of Management

Volume 2, Issue 2, Dec 2016

[23] Naceur S (2003). The determinants of the Tunisian banking industry profitability: Panel evidence. $<$ www.mafhoum.com/press6/ 174E11>.

[24] Ncube, M. (2009). Efficiency of the Banking Sector in South Africa, African Economic Conference 2009 Fostering Development in an Era of Financial and Economic Crises, Addis Ababa.

[25] NRB (2010). Banking supervision annual report, Bank Supervision Department, Nepal Rastra Bank, Central Bank of Nepal.

[26] Oberholzer, M. and Van der Westhuizen, G. (2004). An Empirical Study on Measuring Efficiency and Profitability of Bank Regions Meditari Accountancy Research 12 (1), pp 165-178.

[27] O’Donnell, C.J. and van der Westhuizen, G. (2002). Regional comparisons of banking performance in South Africa. The South African Journal of Economics 70 (3), pp 485-518.

[28] Okeahalam, C., C. (2006). Production costs and efficiency in the South African banking sector: a stochastic analysis. International Review of Applied Economics 20, pp 103-23.

[29] Olweny T, Shipho TM (2011). Effects of banking sectrol factors on the profitability of commercial banks in Kenya. Econ. Financ. Rev., 1(5): 1-30.

[30] Panda, J. and Lall, G.S. (1991), “A Critical Appraisal on the Profitability of Commercial Banks,” Indian Journal of Banking and Finance, Vol.5, No.2, pp. 40-44.

[31] Raza A, Farhan M, Akram M (2011). A comparison of financial performance in investment banking sector in Pakistan. Int. J. Bus. Soc. Sci., 2(11): 72-81.

[32] Samad, A. (2004). Bahrain Commercial Bank’s Performance during 1994-2001. Credit and Financial Management Review 10(1) pp 33-40.

[33] Sampath, S.J. (1990), "Monitoring the Variables Determining the Profitability of Banks," Banking for better Profitability, Vol. 3, No. 2, pp. 691-699.

[34] Sangmi MD, Nazir T (2010). Analyzing financial performance of commercial banks in India: Application of CAMEL model. Pak. J. Commer. Soc. Sci., 4 (1): 40-55.

[35] Sarker, P.C. and Abhiman Das, (199\&), "Development of Composite Index of Banking Efficiency: The Indian Case,” RBI Occasional Papers, Vol. 18, No. 4, pp. 22-28.

[36] Sarker, J., Sarker, S., and Bhaumik, S.K., (1999), "Does Ownership Always Matter? - Evidence from the Indian Banking Industry,” Journal of Comparative Economics, Vol.26, No. 2, pp. 262-281.

[37] Satyamurthy, B., (1994), “A Study on Interest Spread in Commercial Banks in India,” Working Paper, Vol. 21, No.2, pp. 81-92.

[38] Seiford, L., M and Zhu, J (1999). Profitability and Marketability of the Top 55 U.S. Commercial Banks Management Science 45 (9), pp 1270-1288.

[39] Smith M.J. (1988). Contemporary communication research methods. Belmont, CA: Wadsworth, Inc.

[40] Suvita Jha and Xiaofeng Hui(2012), The Use of Key Performance Indicators for a comparison of financial performance of commercial banks: A case study of Nepal. African Journal of Business Management Vol. 6(25), pp. 7601-7611, 27 June, 2012 (by Available online at http://www.academicjournals.org/AJBM DOI: 10.5897/AJBM11.3073 ISSN 1993-8233 @2012 Academic Journals

[41] Tarawneh M (2006). A comparison of financial performance in the banking sector: some evidence from Omani commercial banks. Int. Res. J. Financ. Econ., 3: 101-112.

[42] Toni Uhomoibhi Aburime (2008), "Determinants of Bank Profitability: Company - Level Evidence form Nigeria,” Banking and Finance Research Group, Vol.7, No.3, pp. 133-146.

[43] Uppal, R.K. (2009), "Indian Bnking - Prime Determinants of Profitability, Emerging Issues and Future Outlook,” GITAM Journal of Management, Vol.7, No.2, pp. 78-106

[44] Uzhegova O (2010). The relative importance of bank-specific factors for bank profitability in developing economies/P 2010/02. <http://ssrn.com/abstract=1595751>.

[45] Webb, R.M. (2003). Levels of efficiency in UK retail banks: a DEA window analysis. International Journal of the Economics of Business Vol 10 (3), pp 305-322.

[46] Xuezhi Qin1 \& Dickson Pastory (2012), Key Performance Indicators as Tools in Measuring Commercial Banks Profitability Position: The Case of Tanzania, School of Business Management, Dalian University of Technology, Dalian, China. International Journal of Business and Management; Vol. 7, No. 13; 2012, Published 
by Canadian Center of Science and Education Received: May 24, 2012 Accepted: June 5, 2012 Published: July 1, 2012 doi:10.5539/ijbm.v7n13p136 URL: http://dx.doi.org/10.5539/ijbm.v7n13p136

[47] Yeh, Q., J. (1996). The Application of Data Envelopment Analysis in Conjunction with Financial Ratios for Bank Performance Evaluation. Journal of the Operational Research Society 47, pp 980-988. 